MICROCYSTIS AERUGINOSA REMOVAL BY DISSOLVED AIR FLOTATION (DAF) 


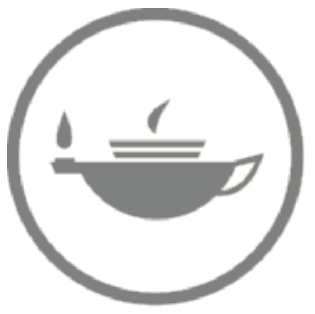

Taylor \& Francis Taylor \& Francis Group

http://taylorandfrancis.com 


\title{
Microcystis aeruginosa Removal by Dissolved Air Flotation (DAF)
}

\section{Options for Enhanced Process Operation and Kinetic Modelling}

\author{
DISSERTATION \\ Submitted in fulfilment of the requirements of \\ the Board for the Doctorates of Delft University of Technology \\ and the Academic Board of the International Institute for Infrastructural, \\ Hydraulic and Environmental Engineering for the Degree of DOCTOR \\ to be defended in public \\ on Monday, 26 January 1998 at 13:30 h
}

\author{
by \\ ALEKSANDAR VLAŠKI \\ Master of Science in Sanitary Engineering (IHE-Delft) \\ born in Skopje, Macedonia
}

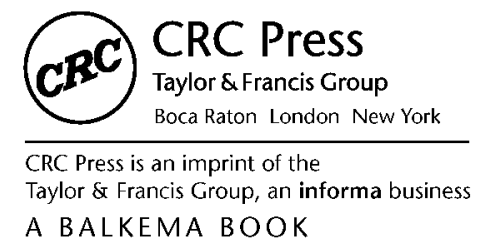


This dissertation has been approved by the promoter:

Prof. dr G.J.F.R. Alaerts Delft University of Technology/International Institute for Infrastructural, Hydraulic and Environmental Engineering

Other committee members:

Chairman:

Co-chairman

Prof. dr J.C. Schippers

Prof. dr K.J. Ives

Prof. ir J.C. van Dijk

Prof. dr ir J. de Graauw

Dr ir A. Graveland
Rector Magnificus, Delft University of Technology

Rector, International Institute for Infrastructural, Hydraulic and Environmental Engineering

International Institute for Infrastructural, Hydraulic and

Environmental Engineering, Delft

University College London, London

Delft University of Technology, Delft

Delft University of Technology, Delft

Amsterdam Water Works

Authorization to photocopy items for internal or personal use, or the internal or personal use of specific clients, is granted by A.A. Balkema, Rotterdam, provided that the base fee of US $\$ 1.50$ per copy, plus US\$0.10 per page is paid directly to Copyright Clearance Center, 222 Rosewood Drive, Danvers, MA 01923, USA. For those organizations that have been granted a photocopy license by $\mathrm{CCC}$, a separate system of payment has been arranged. The fee code for users of the Transactional Reporting Service is: $9054104104 / 98$ US\$1.50 + US $\$ 0.10$.

Published by

A.A. Balkema, P.O. Box 1675,3000 BR Rotterdam, Netherlands

Fax: +31.10.4135947; E-mail: balkema @balkema.nl; Internet site: http://www.balkema.nl

A.A. Balkema Publishers, Old Post Road, Brookfield, VT 05036-9704, USA

Fax: 802.276.3837; E-mail: info@ashgate.com

First issued in hardback 2018

ISBN-13: 978-1-138-47475-8 (hbk)

ISBN-13: 978-90-5410-410-0 (pbk)

(C) 1998 A.A.Balkema, Rotterdam 


\section{Contents}

$\begin{array}{lll}\text { Acknowledgements } & \text { VII }\end{array}$

$\begin{array}{lll}\text { Abstract } & \text { IX }\end{array}$

1. The algae problem in the Netherlands from

a water treatment perspective $\ldots \ldots \ldots \ldots \ldots \ldots \ldots \ldots \ldots$

2. Research objectives, hypotheses and methodology $\ldots \ldots \ldots \ldots \ldots \ldots$

3. Optimisation of coagulation conditions for the removal of

Microcystis aeruginosa by dissolved air flotation or sedimentation . . . . . . . . 39

4. Polyelectrolyte enhanced coagulation and algae conditioning by ozone or $\mathrm{KMnO}_{4}$ in the context of efficient dissolved air flotation

5. Algae laden water treatment by dissolved air flotation (DAF) -

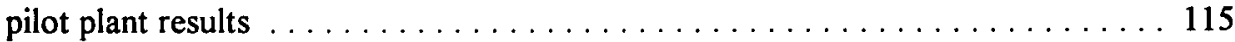

6. The role of floc size and density in dissolved air flotation and sedimentation

7. Dissolved air flotation (DAF) kinetic modelling - a tool for improved process design and operation

8. Extended Summary and Conclusions $\ldots \ldots \ldots \ldots \ldots \ldots \ldots \ldots \ldots$

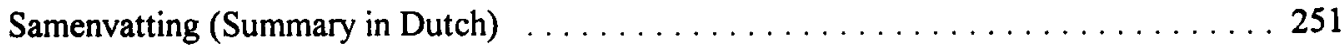

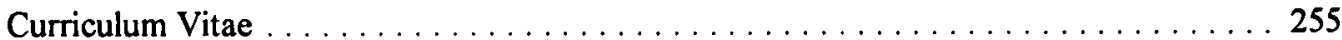




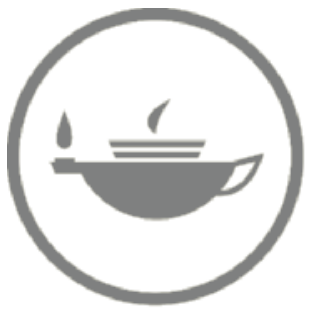

Taylor \& Francis Taylor \& Francis Group

http://taylorandfrancis.com 


\section{Acknowledgements}

My deepest gratitude goes for ir. A.N. van Breemen and Prof. Dr. ir. G.J. Alaerts for entrusting me the opportunity to work on this project. Without the involvement of my mentor ir. A.N. van Breemen who meticulously worked on initiating and organising the research, this project would have never been carried out. Together with my promoter Prof. G.J. Alaerts they formed a team of wide vision, immense theoretical knowledge and broad research experience, giving me the opportunity to learn, develop, direct and critically assess my own research skills and knowledge. They helped me to develop a systematical and analytical approach to technical problems solutions, an invaluable achievement for my future engineering career.

I am most sincerely indebted to the Dutch companies which financially supported this research. I gratefully acknowledge the support of : Amsterdam Water Supply (GWA), North Holland Water Supply Companies (PWN), Rhine-Kennemerland Water Transport Company (WRK), Dune Water Supply Company South Holland (DZH), Energy and Water Supply Company Rhineland (EWR), Water Supply Association Overijssel-Regio Oost (WMO, formerly Water Supply Company OostTwente-WOT), Groningen Water Supply Company (GWG), and KIWA Research and Consultancy. I also wish to express my gratefulness to the representatives of these companies who participated on the Advisory Committee which guided and critically assessed the research in its progress. My thanks go to: Dr. ir. A. Graveland and ir. E.T. Baars (Gemeentewaterleidingen Amsterdam), Dr. P.G.M. Stocks, ing. R.A. Wyatt and ing. N. Koelman (N.V.Watertransportmaatschappij Rijn-Kennemerland), Dr. W. Hoogenboezem (N.V.Provinciaal Waterleidingbedrijf van Noord-Holland), the late ir. J. van Puffelen and ing. P.L. Buijinck (N.V. Duinwaterbedrijf Zuid Holland), Mr. J.H. Heijnen (N.V. Waterleiding Maatschappij Overijssel-Regio Oost), Drs. A. de Ruyter and ing. W. Oorthuizen (N.V. Duinwaterbedrijf Zuid Holland, formerly N.V. Energie en Watervoerziening Rijnland), ir. A.I.A. Soppe and ir. R.T. van der Velde (Gemeente Waterbedrijf Groningen), ir. P.Buys and ir. H. Koppers (N.V. KIWA Onderzoek en Advies), and Drs. G. Bolier (Technische Universiteit-Delft). Their criticism and comments resulted in a praiseworthy quality of the research by combining the theory with the practical aspects of drinking water production.

I also wish to thank Prof. Dr. K.J. Ives (University College London) and Prof. Dr. J.C. Schippers (IHE-Delf) for their involvement, constructive criticism and useful comments on the draft version of the thesis.

I sincerely appreciate the hospitality of the Laboratory for Sanitary Engineering (Faculty of Civil Engineering, Delft University of Technology) which provided the facilities for carrying out the experimental part of the research. The invaluable help of the laboratory staff including Mr. C. Boeter, Mr. T. Schuit and others, in setting-up the experimental facilities and the analytical work and support is highly appreciated. 
My equally sincere appreciations and gratefulness goes for the Laboratory of IHE-Delft. I thank Mr. F. Kruis, Mr. D. Lindenburg, Mr. C. Bik and all the other laboratory staff for their help in the analytical work, but also their kindness and hospitality. My sincere thanks go to Mrs. J. Van Hooijdonk for her priceless contribution in culturing the often unpredictable cyanobacteria used in the research.

I also have to express my gratefulness to the Rhine-Kennemerland Water Transport Company (WRK III, Andijk) for the hospitality in allowing me to carry out the pilot plant research on their premises. The always friendly atmosphere and the cooperativeness of the treatment plant and laboratory personnel will remain in pleasant memories. There I sincerely thank ing. R. Wyatt, ing. N. Koelman, Mr. W.M. Groeneveld, and all the others who helped carry out this not always easy task.

My endless appreciation goes to the enthusiastic and praiseworthy work of the four M.Sc. fellows who participated in the project : Mr. L.O. Karimu, Mr. A.A. Daniel, Mr. F. Merid and Mr. J.S. Hwang. Their commitment and hard work resulted in a valuable contribution to the research.

I would also like to thank to all my colleagues at IHE who provided the solid friendly and scientific background for my stay and research. I shall always praise and treasure the time spent in this environment.

Finally, I thank my wife Valentina and our children Ivana and Josif for centring their lives around my career. I apologise for all the late dinners, raised voices and nervous attitudes. Your support was priceless and shall always be treasured. 


\section{Abstract}

Vlaški A., (1997). Microcystis aeruginosa Removal by Dissolved Air Flotation (DAF) Options for Enhanced Process Operation and Kinetic Modelling. Doctoral thesis, International Institute for Infrastructure, Hydraulic and Environmental Engineering (IHE)/Delft University of Technology (TUD), Delft, the Netherlands, 253 pages.

Seven Dutch surface water treatment companies share the problem of periodical troublesome algal blooms in their raw water sources and reservoirs, and participated in this research : Amsterdam Water Supply (GWA), North Holland Water Supply Companies (PWN), Rhine-Kennemerland Water Transport Company (WRK), Dune Water Supply Company South Holland (DZH), Energy and Water Supply Company Rhineland (EWR), Water Supply Association Overijssel - Regio Oost (WMO, formerly Water Supply Company Oost-Twente - WOT), and Groningen Water Supply Company (GWG). KIWA Research and Consultancy also participated actively in the research.

The eutrophication status of the raw water utilised by the water treatment companies varies substantially. Phosphorus was found to be the limiting nutrient; concentrations of $>0.05 \mathrm{mg} P / \mathrm{L}$ were recognised as potentially troublesome in terms of algal growth (>10 $\mu \mathrm{g}$ chlorophyll-a/L). The predominant algal species depend on a range of additional factors, including $\mathrm{pH}$, temperature, combined ratio of other nutrients, light availability, etc. Different sets of problems are experienced due to the resultant seasonal algal population fluctuations (from $8.4 \mu \mathrm{g} / \mathrm{L}$ chlorophyll- $a$ for Loenderveen Lake to $238 \mu \mathrm{g} / \mathrm{L}$ chlorophyll- $a$ for the PWN reservoir, on a yearly average maximum basis). In all cases however, the periodical peak concentrations of algae cause substantial treatment problems. Cyanobacteria in general and the Microcystis aeruginosa and the Oscillatoria agardhii species in particular, proved to be the most persistent and associated with most treatment problems. The Dutch experiences are generally representative of industrialised countries where increased eutrophication results commonly in algal blooms and related treatment problems. These included an up to $100 \%$ higher coagulant dose, substantially increased filter backwash quantities, trihalomethane formation (during short periods of intermittent chlorination for mussels growth control), (surface) clogging of filters, passing of algae through treatment in objectionable quantities, increase of MFI (modified fouling index) and AOC (assimilable organic carbon) values, etc. The spherical $M$. aeruginosa single cells form is also representative of particles in the size range that are typically difficult to remove in treatment $(3-10 \mu \mathrm{m})$. Its size and shape make it also a suitable representative of the pathogenic Cryptosporidium oocysts and Giardia cysts.

This study targeted the removal of the cyanobacteria $M$. aeruginosa by conventional and advanced treatment technologies, that are available or considered feasible under raw water quality and process circumstances that are typical for the Netherlands. The ultimate barrier preventing them, and their products, from penetrating into the distribution system is rapid or/and slow sand filtration. Pre-treatment modes practised in the involved companies include sedimentation- 
filtration and more advanced dissolved air flotation (DAF)-filtration. The coagulation/flocculation process is of critical importance regardless of the down-stream treatment; however, the downstream treatment itself is defined by the coagulation/flocculation. The option of algae conditioning by oxidants, e.g. ozone or $\mathrm{KMnO}_{4}$, although not actively practised in the Netherlands, was considered attractive to (periodically or continuously) increase the algae removal efficiency. Consequently, this study aimed to investigate a range of treatment options for the removal of $M$. aeruginosa, with an emphasis on DAF and different modes for its enhancement. The evaluation of process efficiency was to be complemented with insight into the process mechanisms, and to serve as a basis for the evaluation of process kinetics.

For this purpose two experimental modes were used: a bench-scale modified jar test filtration apparatus with facilities for both DAF and sedimentation, and a commercial DAF pilot plant (Purac, Sweden). The former utilised model water prepared by spiking water originating from the Biesbosch reservoirs (the Netherlands) with laboratory cultured $M$. aeruginosa to a standard initial concentration of $\approx 10,000 \pm$ cells $/ \mathrm{mL}$. The standard experimental temperature was $20^{\circ} \mathrm{C}$ and coagulation $\mathrm{G}$ was $1,000 \mathrm{~s}^{-1}$ for $30 \mathrm{~s}$ at $\mathrm{pH} 8$. Other coagulation $\mathrm{pH}$ conditions were also tested $\left(\mathrm{pH} \mathrm{4}, 6,7,8\right.$, and 9). The flocculation $\mathrm{G}$ and time were varied $\left(\mathrm{G}_{\mathrm{f}}=10,30,50,70,100\right.$ and 120 $\mathrm{s}^{-1}$ and $\mathrm{t}_{\mathrm{f}}=5,10,15,25,30$ and $\left.35 \mathrm{~min}\right)$. The coagulant $\left(\mathrm{FeCl}_{3} \cdot 6 \mathrm{H}_{2} \mathrm{O}\right)$ doses were $0-15 \mathrm{mg}$ $\mathrm{Fe}(\mathrm{III}) / \mathrm{l}$, while the cationic polyelectrolytes Superfloc C-573 and Wisprofloc-P, the non ionic Wisprofloc-N, and the anionic Superfloc A-100 were tested as sole coagulants and as coagulant aids. Ozone was used as an algae conditioner in the dose range of $0.48-2.16 \mathrm{mg} \mathrm{O}_{3} / \mathrm{L}$, or $0.2-0.9$ $\mathrm{mg} \mathrm{O}_{3} / \mathrm{mg}$ TOC at $\mathrm{pH} 7.5 . \mathrm{KMnO}_{4}$ conditioning was tested in the dose range of $0-2 \mathrm{mg} / \mathrm{L}$ at $\mathrm{pH}$ 8 , the optimal dose being based on the visual determination technique. The $\mathrm{KMnO}_{4}$ contact time was varied from 0-30 min. The DAF pilot plant was (operated at a flow of $Q=4-6 \mathrm{~m}^{3} / \mathrm{h}$ ) followed by a multi media rapid sand up-flow filtration $\left(Q=0.4 \mathrm{~m}^{3} / \mathrm{h}, \mathrm{v}=10 \mathrm{~m} / \mathrm{h}\right)$ and situated at the WRK III treatment plant in Andijk, the Netherlands. It was compared with the full-scale WRK III treatment line comprising of flocculation, lamella sedimentation and filtration, during the cyanobacteria blooms (primarily $M$. aeruginosa) occurring in the raw water reservoir. Analytical techniques for the assessment of process efficiency included turbidity, residual coagulant ( $\mathrm{Fe}$ ), TOC/DOC, UV absorbance at $254 \mathrm{~nm}$, and residual Mn. They were supported by more advanced methodologies including bromate and MFI measurements, particle count (in the size range of $d_{p}>2.75 \mu \mathrm{m}$ and in a limited number of cases $\left.d_{p}>0.3 \mu \mathrm{m}\right)$ and computer image analysis $\left(d_{p}>1.9\right.$ $\mu \mathrm{m}$ ). Coupled with the high resolution SEM (scanning electron microscopy), the latter provided valuable information for assessment of process mechanisms and kinetics.

DAF proved to be a viable and efficient alternative to sedimentation for the treatment of heavily algae ( $M$. aeruginosa) laden water. It consistently resulted in equal or better algae removal efficiency than the sedimentation process ( $71 \%$ versus $87 \%$ for jar test conditions, and $96.3 \%$ versus $95.9 \%$ for pilot plant conditions), requiring at the same time an up to $50 \%$ lower coagulant dose than the sedimentation $(3 \mathrm{mg} \mathrm{Fe}(\mathrm{III}) / \mathrm{L}$ versus $10 \mathrm{mg} \mathrm{Fe}(\mathrm{III}) / \mathrm{L}$ in the jar test conditions, and $7-12 \mathrm{~g} \mathrm{Fe}(\mathrm{III}) / \mathrm{m}^{3}$ versus $20-24 \mathrm{~g} \mathrm{Fe}(\mathrm{III}) / \mathrm{m}^{3}+0.2-0.5 \mathrm{~g} \mathrm{Wisprofloc}-\mathrm{P} / \mathrm{m}^{3}$ in the pilot plant conditions and the full scale sedimentation), which is significant from an environmental point of view. Also, the produced sludge was of high solids content. Other positive aspects included the relatively short flocculation time (however, not shorter than $15 \mathrm{~min}$, compared to $>30 \mathrm{~min}$ for sedimentation) and the low flocculation energy input requirement $\left(G=10 \mathrm{~s}^{-1}\right.$ compared to $G=30$ $\mathrm{s}^{-1}$ for sedimentation), as well as the high process loading rate (leading to 5-6 times overall lower space requirements). Furthermore, the DAF-filtration treatment scheme resulted consistently in 
high (>2 log) algae removal efficiency. The relatively low coagulant demand for DAF, however, produced less efficient sweep coagulation conditions than in the case of the sedimentation, resulting in organo-Fe complexes formation and consequently higher DAF effluent $\mathrm{Fe}$ and turbidity residuals. This was overcome by coagulation at $\mathrm{pH}<\mathrm{IEP}$ (iso-electrical point), suggesting the potential of using cationic polyelectrolyte coagulant aids. These improved the particle (algae) removal efficiency significantly in case of the model water experiments (20-40\%), compared to a minor rise of only $1-2 \%$ in pilot plant experiments. This is owed to the promotion of particle (algae) adsorption coagulation based on charge neutralisation. Furthermore, the observed charge neutralisation phenomena resulted in improved particle-bubble attachment and hence more efficient DAF. Non-ionic and anionic polyelectrolytes (and the bridging mechanism) were found to be less efficient, partly because of the lower particle concentration (lower coagulant dose) and the negative charge of the air bubbles.

The particle (algae) removal efficiency the pilot plant achieved on reservoir water was by $20-30 \%$ higher than that in the jar tests with model water. The NOM (natural organic matter) concentration and composition was found to be the likely cause of the differences, especially as it is present in the form of organic matter meshes and fibrilar structures. Although the complexing of metal coagulants by NOM imparts additional coagulant demand, these structures may eventually promote flocculation, serving as sites for easier floc growth and embedment, as well as providing a gel-like structure that is easier to be removed by the rising air bubbles in DAF.

Relatively low doses of ozone $(0.2-0.5 \mathrm{mg} \mathrm{O} / \mathrm{mg}$ TOC, or $0.6-1.5 \mathrm{mg} \mathrm{O} / \mathrm{L})$ as an algae conditioner under bench-scale conditions significantly (by 30-40\%) increased DAF efficiency towards 2 log removal. Combined with cationic polyelectrolytes, the DAF process efficiency rose further typically by another $5 \%$. Although not yet confirmed by pilot plant results with reservoir water, the application of the lower dose range of $0.2 \mathrm{mg} \mathrm{O} / \mathrm{mg} \mathrm{C}$ at $\mathrm{pH} 7$ resulted in bromate levels within the range of the $10 \mu \mathrm{g} / \mathrm{L}$ MAC prescribed by the EU. The further improvement of organic matter removal by down-stream GAC (granular activated carbon) filtration would enhance interest in this treatment, especially if ozone is already used for other purposes within the plant (e.g. disinfection), and providing the MAC value remains within the currently prescribed range.

The use of $\mathrm{KMnO}_{4}$ as an algae conditioner also tended to increase DAF process efficiency towards 2 log particle removal, resulting in equal or better performance than the full-scale conventional sedimentation, on occasions even better than the full-scale sedimentation + filtration in terms of particle $\left(d_{p}>2.75 \mu \mathrm{m}\right)$ removal. However, the resultant higher effluent $\mathrm{Fe}$ (organo-Fe complexes) and $\mathrm{Mn}$ (mostly $\mathrm{MnO}_{2}$ ) concentration raised the particle count in the colloidal size range $(<0.5 \mu \mathrm{m})$ and the turbidity. This situation improved when cationic polymers were introduced as coagulant aids, significantly improving the DAF process efficiency (typically by $5 \%$ ) on the account of reduced $\mathrm{Fe}$ and $\mathrm{Mn}$ residuals below their respective MAC values. This option, however, did not lower the accompanying filtrate MFI value to the desired $5 \mathrm{~s} / \mathrm{L}^{2}$ value. The lowest MFI value achieved by the non-optimised filtration (within the DAF + filtration scheme) was in the range of $20 \mathrm{~s} / \mathrm{L}^{2}$. This suggests the need for optimisation of the filtration step to fully utilise the conditioning benefits of $\mathrm{KMnO}_{4}$.

The improved algae removal in the case of conditioning by an oxidant is probably caused by a number of process mechanisms. Motile algal cells are immobilised by the oxidation of the outer 
XII

cell layer, and their metabolic processes are disrupted. This is accompanied with the creation of stress conditions in the algal environment, resulting in EOM (extra-cellular organic matter) excretion, partial algae lysis and IOM (intra-cellular organic matter) leakage. The EOM and IOM act as natural coagulant aids, resulting in spontaneous microflocculation even before coagulant addition. Oxidation and removal of the organic coating on the particles, as well as oxidation of NOM, result in more favourable coagulation conditions through the production of in-situ coagulant, which otherwise would have been complexed and unavailable for coagulation. The resultant $\mathrm{MnO}_{2}$ in the case of $\mathrm{KMnO}_{4}$ conditioning increases the particle concentration and promotes sweep coagulation.

The particle size frequency and volume distributions obtained under different process conditions and after different process stages served as the basis for an empirical calculation of the relative and absolute floc density, an input variable in the single collector collision efficiency DAF reaction zone model. Other input variables such as the mean particle (floc) and bubble size, as well as their number and volume concentrations, were also directly measured or calculated. The calculated values for the particle-bubble attachment efficiency $\alpha_{\mathrm{pb}}$ support the previous assertion regarding the positive impact of cationic polyelectrolytes, and conditioners. Results suggest that under optimal DAF process conditions almost every second particle (floc)-bubble collision resulted in their attachment. The role of the recirculation ratio (5-10\%) and the saturator pressure (500-700 $\mathbf{k P a}$ ), although significantly affecting the bubble size distribution, proved less important for DAF process efficiency. Thus, critical attention should be paid to the coagulation/flocculation process as the major determinant of DAF efficiency. Although difficult to model, the impact of NOM concentration and characteristics on the particle-bubble attachment efficiency is of great significance. Thus, the simplified modelling approach that particle-bubble agglomeration is solely the result of their collision is not fully justified.

DAF proved to be an efficient, robust and flexible water treatment process, and a highly appropriate alternative to sedimentation for the treatment of algae laden water. The lower civil engineering costs and chemicals consumption often will compensate for the higher energy and maintenance costs. Its high algae removal efficiency makes it particularly attractive as pretreatment before direct filtration, or membrane filtration. Where it is already applied, it's efficiency can be significantly enhanced temporarily (e.g. during short or long term algae blooms) by the application of e.g. cationic polyelectrolytes, oxidants, or a combination of the two. The application of $\mathrm{KMnO}_{4}$ seems particularly attractive, since no hazardous by-products are produced. Similarly existing sedimentation units can be retrofitted with (enhanced) DAF in case of increased algae problems. Nevertheless, the final choice of the treatment technology or mode should be made after pilot plant investigations and cost-benefit analysis. 


\section{Chapter 1}

THE ALGAE PROBLEM IN THE NETHERLANDS FROM A WATER TREATMENT PERSPECTIVE

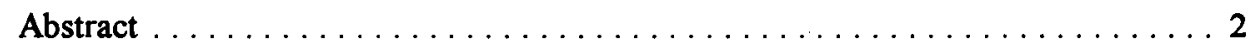

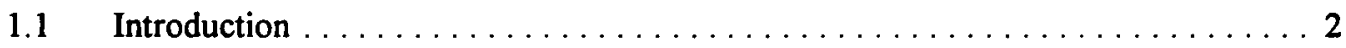

1.1.1 Algae in water supply - a growing concern $\ldots \ldots \ldots \ldots \ldots \ldots \ldots 2$

1.1.2 Eutrophication and algae ........................ 3

1.1.3 Growth strategies and characteristics of cyanobacteria $\ldots \ldots \ldots \ldots \ldots \ldots 5$

1.1.4 Microcystis and Oscillatoria $\mathrm{spp} . \ldots \ldots \ldots \ldots \ldots \ldots \ldots \ldots \ldots$

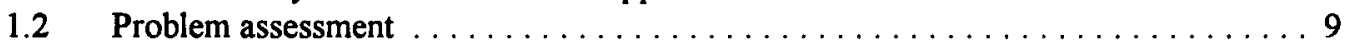

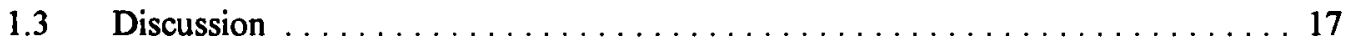

1.3.1 Algae and water treatment - problems and remedies $\ldots \ldots \ldots \ldots \ldots 17$

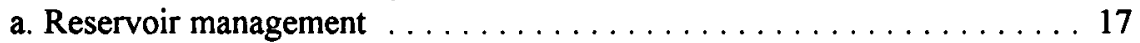

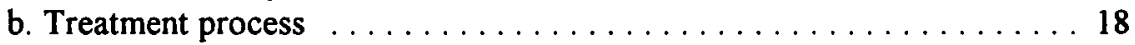

1.3.2 Dissolved air flotation (DAF) - a viable solution option $\ldots \ldots \ldots \ldots \ldots 21$

1.3.3 Agglomeration (coagulation/flocculation) of algae ............ 23

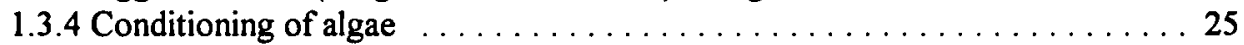

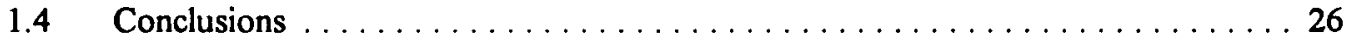

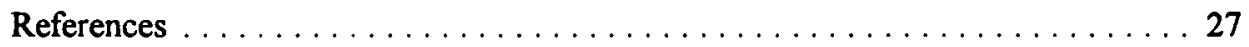

-This chapter is based on A. Vlaski, A.N. van Breemen and G.J. Alaerts (1996), The algae problem in the Netherlands from a water treatment perspective, J. Water SRT-Aqua, 45, 4, pp.184-194, and The algae problem in the Netherlands, problem analysis and treatment strategies in five water treatment companies, (1994) Working Paper EE-1, IHE, Delft. 


\begin{abstract}
Surface water treatment in the Netherlands receives increased attention requiring better characterisation and evaluation of the 'algae problem'. Investigations and analysis carried out at five drinking water production locations in the Netherlands utilising surface water (amounting to $60 \%$ of the overall Dutch surface water production) show that the most significant problem are the cyanobacteria. Seasonal blooms of Microcystis aeruginosa and Oscillatoria agardhii force short- and long-term process modifications, affecting water production cost. Assessment of possible solutions suggests that, apart from the application of appropriate water quality management measures, new insights on more efficient (pre)treatment processes are critical. In treatment, the agglomeration (cuagulation/flocculation) phase is considered the essential step in the removal of the algae. It should be optimised in relation to the pre-treatment preceding it (e.g. application of chemical oxidant/s, and/or microstraining), as well as to the applied solid-liquid separation treatment process. Dissolved air flotation (DAF) emerges as a feasible option given the natural tendency of algae to float. The existing discrepancies between literature and practice call for further research on process mechanisms and suggest that considerable gains can still be made in process optimisation. This research should notably increase insight into the influence of algae morphology and physiology on treatment efficiency.
\end{abstract}

\title{
1.1 INTRODUCTION
}

\subsubsection{Algae in water supply - a growing concern}

VEWIN (the Association of Dutch Water Supply Companies) forecasts the drinking water production in the Netherlands to amount to $1360 \mathrm{Mm}^{3} /$ year by the year 2000 , of which $16 \%$ (220 $\mathrm{Mm}^{3} /$ year $)$ will originate from treated surface water, another $16 \%\left(220 \mathrm{Mm}^{3} /\right.$ year $)$ from duneinfiltrated water, and the remainder $\left(930 \mathrm{Mm}^{3} /\right.$ year) from groundwater [1]. Although this projection for all the sources shows a substantial amount of the infiltrated water is of surface water origin, surface water is not recognized by VEWIN as the preferred alternative. Very often it contradicts one or more of the four basic principles that have to be met for any water source : (i) good water quality, (ii) constant water quality, (iii) low treatment cost and (iv) security from calamities. Nevertheless, surface water is an inevitable choice due to increased water consumption and increasing number of restrictions on groundwater abstraction. The main surface water sources in the Netherlands are the rivers Rhine and Meuse. These two rivers receive a substantial industrial, municipal and agricultural pollution load, resulting in water treatment problems such as high turbidity, colour, organic micropollutants content and high nutrient loads. Eutrophication is recognized as the cause of numerous problems, both in surface water quality and in drinking water treatment. It causes plankton blooms in stagnant and slowly flowing water bodies; their removal emerges as a priority problem in surface water treatment.

Algae cause a wide range of technical and health problems in the treatment and in the distribution step [2]:

i) problems related to algae laden water treatment:

- interference with coagulation and flocculation;

- increased disinfectant demand of the water;

- production of haloform precursors;

- filter clogging and increased use of backwash water; and 
- filter penetration;

ii) problems related to algae presence in the distribution system:

- taste and odour;

- precipitation of algal mucopolysacharides at low $\mathrm{pH}$;

- corrosion of iron mains and discolouration of water;

- shielding of pathogenic bacteria from disinfection;

- aftergrowth of bacteria and higher organisms in the mains;

- infestation of zooplankton; and

- release of toxins.

Nevertheless, water supply experts disagree about the required degree and approach to algae removal in water treatment. Lacking a proper water quality standard, one has to rely on the philosophy that the more algae are removed during common treatment, the better, accepting however that removal efficiency for different types of algae varies widely. The diversity of algal species with respect to their size, form, surface characteristics, production of extra-cellular organic matter (EOM), motility, etc., makes it almost impossible to propose a simple solution that fits water quality management and treatment concerns. Therefore, the 'best available technology' for treatment tends to set the standards.

This chapter intends to address the issue of raw water quality for five Dutch surface water resources, contributing to approximately $60 \%$ of the total surface water origin treated water in the Netherlands. Statistical analysis of the water quality parameters contributing to the eutrophication phenomenon will be performed. This will be related to the resultant impact on the algal population, quantity- and species-wise, defining the most significant species from the point of view of imparted treatment problems. The treatment problems, as well as the adopted short and long term reservoir management and treatment strategies will also be discussed. Finally, an overview of existing conventional treatment technologies, as well as more advanced options for their enhanced operation, will be discussed in the context of most efficient algae removal in drinking water treatment.

\subsubsection{Eutrophication and algae}

Long term changes in the nutrient supply to water bodies cause shifts in the balance and spectra of resources to which phytoplankton is known to respond quantity- and quality-wise. Such changes occur naturally due to a variety of causes. The large increases in the amount of nutrients discharged into water bodies during the past decades, especially in the industrialized countries, and the subsequent changes in the ecology of these water bodies, have called attention to the problem of nutrient enrichment, or eutrophication. Generally, the adjective 'eutrophic' (='well feeding') is used to describe biological aquatic systems with a high input of otherwise growth limiting nutrients, and which therefore support a high level of organic productivity [3].

Eutrophic conditions occur naturally (by leaching of soils and vegetation decomposition), but are nowadays primarily due to human activities (domestic sewage, agricultural run-off, etc.) [4]. The anthropogenic eutrophication, should be tackled at the source of the nutrients discharge, rather 
than by the symptoms. In the Netherlands, as well as in some other West European countries, measures like tertiary sewage treatment and a ban on detergent phosphate have drastically reduced nutrient inputs. However, the nutrient rich under-water sediments, the contained fertilizer use in agriculture, and the inevitable leaching of $N$ and $P$ from wastewater, will keep the trophic levels high.

Eutrophication manifests itself as increased water fertility which results in higher primary productivity, i.e. algal growth. Under extreme conditions this can lead to temporary excessive algal biomass and ecosystem instability. As a result of increased eutrophication, the diversity of algae, especially with respect to the planktonic forms, is reduced in favour of large concentrations of a limited taxonomic range of cyanobacteria, chlorophytes and diatoms. The trophic level of the water body thus defines the range and concentration of species present within it [3].

A common annual cycle for eutrophic impounded water in northern temperate regions like the Netherlands consists of a spring population of diatoms which may include Asterionella formosa, Fragilaria crotonensis, Tabellaria flocculosa, Melosira spp., Cyclotella spp., Stephanodiscus astraea, and/or $S$. hantzschii. During early summer, diatoms may be replaced by small species of cryptophyceae or chlorophyceae, and at a later stage by dinoflagellates such as Ceratium hirundinella, chrysophytes such as Dynobrion spp., Synura spp., or chlorophyte genera such as species of Chlorella, Scenedesmus, Dictyosphaerium, Ankistrodesmus, Eudorina and Pandorina. However, in late summer and throughout autumn, dominant populations of cyanobacteria (bluegreen algae) may occur, including Anabaena spp., Aphanizomenon flos-aquae, Gloeotrichia, and Coelosphaerium; especially Microcystis aeruginosa and Oscillatoria spp. can be abundant and are able to form surface blooms of aggregated cells under windless conditions [4].

In addition, cyanobacteria tend to dominate a large part of the growing season. Objectionable odours may emanate from water bodies due to decaying biomass, and the water may suffer from offensive tastes and odours, while serious disruption of water treatment processes is experienced. Predation of algae is reduced by colony forming and filamentous cyanobacteria, resulting in the preclusion of effective filter feeding zooplankton (algae size related). This further influences the plankton abundance and composition. In addition, toxins produced by cyanobacteria, such as microcystin, have been responsible for occasional outbreaks of wildlife and livestock illness and death, and has been related to human illnesses [4].

Principles of freshwater ecology phytoplankton form the basis for appropriate design and management strategies of lakes and reservoirs [3]. On the other hand, knowledge of the freshwater ecology does not guarantee the accurate prediction of the plankton responses to particular changes in their environment. Furthermore, the primary problem of water treatment engineers in practice is the problem of biomass 'peaks', composed of different dominant species, regardless of the average level of biomass. Therefore, more knowledge is needed on the behaviour and characteristics of individual organisms. This knowledge should preferably overcome the indiscriminative algae related lumped material parameters approach (chlorophyll, organic carbon, turbidity, etc.). Species differ in their ecological, morphological and physiological characteristics that allow them to survive and grow, and that can strongly influence water treatment. 


\subsubsection{Growth strategies and characteristics of cyanobacteria}

The spatial and temporal distributions of an organism within an ecological system are the result of the evolutionary strategies the organism adopted for growth and survival [5]. Strategies can be defined as sets of similar morphological, physiological, reproductive or behavioural traits that have evolved among species or populations and that are better suited to particular environmental conditions than that of others. Accordingly, different organisms that adopted similar strategies, are likely to resemble in their ecological behaviour.

Based on the logistic growth equation phytoplankton communities have commonly been classified into two main categories : $r$ (characterised by rapid growth and colonisation of a nutrient rich environment) and $K$ (characterised by the ability to out compete other organisms in a nutrient limited environment) [3]. However, other approaches exist that are seemingly more suitable for algae and which classify organisms into three categories marked $C, S$ or $R$ [5]:

- C/competitors : exploitation of environments saturated with light and nutrients, through the investment in rapid growth and reproduction, and to do so before other species;

- S/stress tolerant : operation under conditions of severe depletion of externally supplied essential nutrients; and

- $\mathrm{R} /$ ruderals : tolerate frequent or continuous turbulent transport through the light gradient.

There is a considerable overlap of morphometric and physiological characteristics (e.g. unit volume, surface area/volume, maximum linear dimension, photosynthetic efficiency, projected area, maximum growth rate, cellular phosphorus uptake, temperature sensitivity, threshold dose of exposure to saturating light intensity, motility, minimum sinking rate and susceptibility to grazing) of these classes, but the growth and recruitment of a particular strategist will be preferentially promoted in function of specific environmental circumstances. These species. are then more likely to build up the largest fraction of sustainable biomass (i.e. become dominant) for as long as the same circumstances persist.

Environmental variables that are supposed to influence the selection among the primary strategists (C, S or R) may be grouped as physical factors (e.g. temperature, stability of the water column, absolute mixed depth, turbidity of mixed layer), chemical factors (notably nutrient concentration) and biotic factors (grazers filtering rate). These may be referred to as externally imposed (allogenic) perturbations. On the other hand, self-imposed (autogenic) perturbations play a substantial role in the definition and selection among the strategists, like euphotic depth (depth of light penetration), reduction due to high biomass concentration, nutrients concentration decline, or increased rate of zooplankton grazing.

Extreme eutrophication expressed in a range of unusual physio-chemical conditions has been proven advantageous to the physiologically and ecologically adaptive cyanobacteria. Ideally, physical and to a lesser extent chemical stability must accompany such extremes. The more a species is versatile in adapting itself to a wider set of survival associated factors, the more abundant, and the longer lasting is its population during the yearly cycle [5]. The cyanobacteria have proven to be highly versatile and adaptable, able to survive and to dominate in conditions highly unfavourable for other species. This versatility makes cyanobacteria able to survive and dominate in water bodies during protracted periods of the annual plankton cycle. In some 
relatively large and shallow lakes, e.g. the Hartbeespoort Dam and the Vaalkop Dam in South Africa, cyanobacteria compose the most significant part of the population throughout the year; this situation probably reflects a final eutrophication stage of a lake, considering the comparatively constant climatic and nutrient conditions [6].

Carbon, nitrogen and phosphorus are the essential nutrients for cyanobacteria. The nutrient uptake pattern influences the population structure in the water body. It has been noticed that high phosphorus levels generally result in cyanobacterial dominance, though blooms also occurred in low or undetectable phosphate concentrations [7]. The latter is probably caused by fast and almost complete uptake of phosphate by blooming species, leaving the water with low phosphate concentrations for a period of time. A large diversity in response towards phosphorus deficiency has been found, with little or no growth rate dependence on external (i.e. soluble reactive phosphorus, or total dissolved) phosphorus. The rate of phosphate uptake is optimal between $\mathrm{pH}$ 7.5 and 8.5 and declines sharply below neutral $\mathrm{pH}$; it is larger in light than in dark conditions.

Most cyanobacteria are $\mathrm{N}_{2}$ fixing organisms [7]. Fixation of dissolved atmospheric $\mathrm{N}_{2}$ fixation is carried out by unicellular organisms, by filamentous, heterocystic forms (such as Anabaena and Nostoc) and by filamentous strains lacking heterocysts (heterocysts and akinetes emerge in nutrient exhausted surroundings, akinetes having a preservatory role and being able to germinate in better nutrient conditions).

The role of carbon in the nutrition and life cycle of cyanobacteria is still not sufficiently clarified, but together with nitrogen it is readily available from the atmosphere, unlike phosphorus. The deficiency in nitrogen and phosphorus is known to lower the respiration rate, and causes accumulation of carbohydrates during the light period of the day, preparing cells for survival in the dark [7].

Cyanobacteria depend on efficient photosynthesis. Like other taxa, they show phototactic/phobic and chemotactic/phobic responses, indicating their affinity to light and limnological conditions. Cyanobacteria, however, are versatile and adaptive, which allows them to out compete other algae in unfavourable environments with regard to nutrients and light. They can adapt to the light-dark regime in a way that gives them the possibility to maintain a higher photosynthetic activity during short photoperiods, so that they may survive for prolonged periods in the dark. They can also adapt to irradiance intensity, whereas a planktonic species from a temperate lake may be killed by prolonged exposure to irradiance exceeding a certain high intensity. A characteristic adaptive mechanism adjusts their chlorophyll content to the light's wave length, to maximize lightefficiency [7].

Cyanobacteria also show motility within the water column. Two types of movement are exerted by cyanobacteria when searching favourable living conditions [7]: phototactic gliding of cyanobacteria attached to surfaces (of suspended sand, clay particles, etc.), and light regulated buoyancy. The rate of displacement, and the frequency of path reversals are related to e.g. the vertical movement in a water body, and are influenced by temperature, viscosity and chemical factors. On the other hand, factors that change rapidly or a concentration gradient, like light intensity, wind and chemical factors, influence the direction of the movement. 
Finally, circumstantial evidence exists that some cyanobacteria secrete organic substances of which some are inhibitory or toxic to other organisms, including fish, waterfowl domestic livestock, and humans [3]. An assessment from almost 300 sites all over the world, in the period 1981-1989, shows that the likelihood of an individual bloom being toxic is $45-75 \%$. Usually, Microcystis, Anabaena, Oscillatoria and Aphanizomenon, and less often Gomphosphaeria, Coelosphaerium, Nodularia, Nostoc and Cylindrospermum, were involved [8]. Research conducted on toxic algae blooms in the UK in 1989 indicated associated death of dogs and sheep, and illness in people. The toxicity was attributed to microcystin poisoning, originating from $M$. aeruginosa. Such blooms and associated toxicity were also recorded in Norway, Denmark, Sweden, USSR, Finland [8], Australia [9] and Brazil [10]. In Finland, cattle poisoning attributed to cyanobacterial blooms took place at three sites in 1985 and 1986, and similar blooms occurred in drinking water sources as well. The isolation of strains of cyanobacteria confirmed the presence of hepatotoxic and neurotoxic strains of Anabaena, as well as hepatotoxic strains of Microcystis and Oscillatoria [11]. The National Rivers Authority in UK reported in 1990 about the 1989 cattle kill and human infestations. $68 \%$ of the 78 water bodies tested for toxicity were found positive, which was related mostly to the presence of $M$. aeruginosa, though other cyanobacteria were present as well, notably Aphanizomenon flos-aquae, Anabaena, and Oscillatoria [6]. In 1990 the incidence of Anabaena spp. bloom in a recreational lake in the Netherlands was found to have caused summer flu in humans. Toxicity analysis of water containing Microcystis spp. blooms and originating from the Andels Meuse and Braassemer Lake in the Netherlands showed the presence of hepatotoxic microcystin toxin, This led to the conclusion that consumption of these toxins via drinking water is possible [12]. Further research was advocated on the influence of environmental factors on the characteristics and levels of cyanobacterial toxicity, as well as on the stability and persistence of the toxins involved.

No consensus exist in literature on the question whether cyanobacterial toxins are relevant from the point of view of water treatment and distribution. However, it is suggested that the public health aspect should receive more attention. Distinction is to be made between physical contact with surface water containing cyanobacterial toxins, consumption of such water, and consumption of water that contained cyanobacteria before treatment. Similarly, it still is uncertain whether the toxic substances, rarely identified, are secreted by viable algae, or whether they are produced during putrescence of algal matter [3]. Significant levels of toxins found during water treatment may be provoked by cell lysis due to for example oxidants application.

Controversy also exists regarding the nature of the human infestations caused by ingestion of cyanobacterial toxins. Some species of cyanobacteria have been identified as causing gastroenteritis, however, only when consumed in large numbers [13]. High cyanobacteria concentrations in the raw water supply have been found to cause an epidemic of pyrogenic reaction among kidney patients consuming such water [14]. Lysis of cyanobacteria, when an algicide or oxidant disinfectant is applied, may result in harmful concentrations of toxins in domestic water supplies causing liver injury, gastroenteritis, or hepatoenteritis [15]. Others on the other hand, state that conclusive evidence exists that cyanobacterial toxins are a health hazard in drinking water [4].

However, not all cyanobacteria species are toxic, and differences exist between strains of the same species. The recognition of different environmental conditions (nutrient composition, light availability, presence of competitor algae species, etc.) and the governing mechanisms which may 
result in differing toxicity of the same strain at different locations, has not been addressed so far and deserves further research attention.

In conclusion, it appears that the excretion of toxins is a widely recognized problem, and that high cyanobacteria concentrations warrant much caution. It is therefore recommended that a careful approach is adopted to the application of certain chemicals such as oxidants (e.g. ozone or $\mathrm{KMnO}_{4}$ ) as particle (algae) conditioners due to the potential danger of toxins leakage from ruptured algae cells. The fate of toxins along the treatment line, especially the final product toxin levels deserves research attention. The issue of long term toxins consumption and health implications has not been addressed so far and also attracts attention. The recommended approach is to face and assess the potential toxicological problems regardless of the high cost and long duration of such analysis.

\subsubsection{Microcystis and Oscillatoria spp.}

Whilst cyanobacteria species are generally recognized as K-strategists, species differ with regard to their $\mathbf{R}$ or $\mathbf{S}$ character. The most widely spread cyanobacteria are Microcystis spp., which are characteristic for eutrophied lakes, and a typical S-species, able to dominate periods of late summer (high temperatures), and severe nutrient depletion. Their physiological and morphological characteristics make them a particular nuisance in water treatment. On the other hand, in the Netherlands concern grows about the incidence of the Oscillatoria spp. in some water resources. Oscillatoria spp. are known to possess an effective light-capturing mechanism across a wide band of the visible spectrum, as well as a buoyancy regulating mechanism. These make for a pronounced R-species, allowing the species to inhabit constantly mixed lake environments [5]. There is obvious differentiation between these two cyanobacterial genera, with respect to their shape, size, extra cellular organic matter (EOM) characteristics, nutrient uptake, buoyancy regulating mechanism, etc. On the other hand, they are both identified as cause of numerous problems in water treatment $[4,6,8,12,16,17,18]$. Therefore, they are of particular further interest to this study.

Microcystis spp. are encountered worldwide. They are spherical in shape, of 3-7 $\mu \mathrm{m}$ in size, and can occur in irregularly shaped colonies of often more thousands cells, as well as single cells. There are indications that the single cell form is an adaptation of this species developing at later stages of their life cycle (i.e. later during the season), due to the dissociation of colonies in order to provide better light availability for all cells. These species favour warmer water $\left(>14^{\circ} \mathrm{C}\right)$ and stable, relatively low nutrient availability, combined with stable hydraulic conditions $[3,16]$.

Oscillatoria spp. are characterized by an oscillating movement and lack of definite sheath. Their cells exceed $100 \mu \mathrm{m}$ in length and are 3-5 $\mu \mathrm{m}$ in diameter; trichomes are solitary or intermingled, forming non-parallel bundle-like structures. Generally, they inhabit temperate lakes of two distinct types : (i) mildly eutrophied, large, deep, and usually alpine lakes, and (ii) shallow, enriched, unstratified basins, where they form stable maximum concentrations in the summer metalimnion, provided that this is located within the euphotic zone. They possess an extremely efficient light capturing mechanism, functional across a wide band of the visible spectrum, favouring low irradiance and achieving maximum growth rates at relatively low nutrient availability [3]. 
Cyanobacteria in general, and especially Microcystis spp., are also able to survive in conditions unfavourable for other species. For example, Microcystis spp. can overcome $\mathrm{O}_{2}$ toxicity. With the high light irradiance of late summer, and high $\mathrm{O}_{2}$ concentrations and low $\mathrm{CO}_{2}$ concentrations, $\mathrm{O}_{2}^{-}$ (superoxide) is produced that damages cytochromes, pigments and other segments of the algal photosynthetic system. To prevent the toxicity of $\mathrm{O}_{2}^{-}$the enzyme superoxide dimutase (SOD) is manufactured in algal cells. However, prolonged high light intensity triggers a drop in SOD level and die-off of algae. This phenomenon has been observed with most algal species, except for Microcystis spp. which are able to maintain high levels of SOD and survive such conditions [7].

Characteristic for Microcystis spp. and Oscillatoria spp. is the existence of gas vacuoles [7]. Up to 10,000 of these organelles are present in a single cell. Generally they have the shape of a hollow cylinder of $70 \mathrm{~nm}$ diameter with a conical cap at each end. They are composed of protein, the wall being permeable to dissolved gases in surrounding liquid, but unpermeable to liquid (the pressure inside being usually atmospheric). Nutrients as well as $\mathrm{Cl}^{-}$and $\mathrm{K}^{+}$uptake are known to play a major role in rise or fall of turgor (difference in hydrostatic pressure between the inside and outside of the cell) and consequent buoyancy. This enables the cells to attain an as good as possible position in a water body (mostly in the vertical sense) with regard to light and nutrients [7].

Other characteristics of the genera establishing their dominance are : allelopathy and light attenuation [7]. Allelopathy involves chemical inhibition of other organisms by the excretion of inhibitory organic compounds. Attenuation of light occurs as the cyanobacteria can increase their biomass very fast, thus increasing turbidity and limiting the growth of competitors. Cyanobacteria are vertically motile during diurnal or higher order nutrient fluctuations, favouring them as inhabitants of water bodies during the late summer and autumn. In addition Oscillatoria spp. are able to maintain approximately neutral buoyancy, and cannot be ingested by grazing zooplankton because of their length of $>100 \mu \mathrm{m}$, ensuring low loss rates [3]

However, characteristic differences exist between the two genera with respect to nutrient affinity and uptake. Oscillatoria spp. have been reported to fix nitrogen [3]. Microcystis spp. in contrast, have been reported as non-nitrogen-fixing species [7]. Low N/P ratios can be expected to favour $\mathrm{N}_{2}$ fixing Oscillatoria spp., whilst the opposite would favour the growth of Microcystis spp.

The toxins related to cyanobacteria blooms may be grouped into three families: neurotoxins, lipopolysacharide endotoxins, and hepatotoxic peptides. Microcystin belongs to the hepatotoxic family and is a potent and specific in vitro inhibitor of phosphatases, with an action similar to that of the tumour promoting toxin of shellfish poisoning, okadaic acid. This particular toxin, consists of polypeptide containing D-serine, L-orithine and some protein L-amino acids (circular peptide) $[8,16]$.

\subsection{PROBLEM ASSESSMENT}

Analysis of operational data of five major surface water treatment plants in the Netherlands has been performed, of which a representative cross-section is given in Table 1.1 [19]. These all produce water for different purposes (drinking water, industrial water and dune infiltration water), and face growing problems caused by algae. They are interested in efficient short- and long-term 
treatment strategies and process modifications to address the algae problem. The enterprises are North Holland Water Supply Companies (PWN), Rhine-Kennemerland Water Transport Company (WRK), Dune Water Supply Company South Holland (DZH), Amsterdam Water Supply (GWA) and Energy and Water Supply Company Rhineland (EWR). At a later stage of the research after the further presented analyses were completed, two more enterprises with similar interests were involved, namely Water Supply Association Overijssel - Regio Oost (WMO, formerly Water Supply Company Oost-Twente - WOT), and Groningen Water Supply Company (GWG) (Fig.1.1).

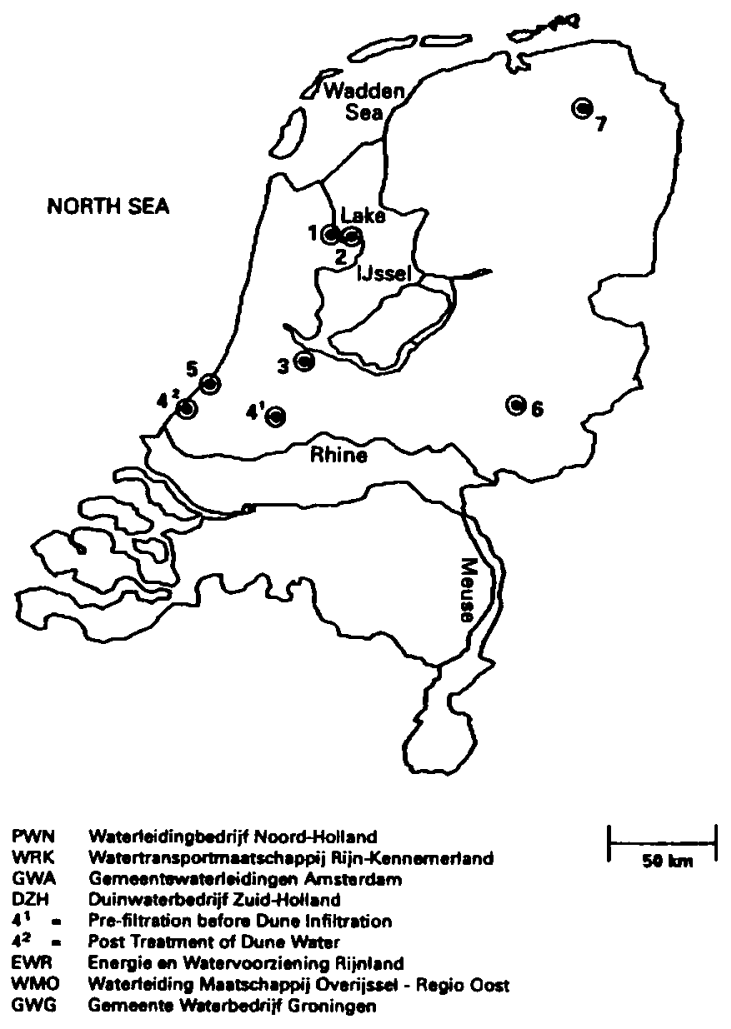

Fig. 1.1 Locations of the water treatment plants of the seven water treatment enterprises.

Although the origin of all concerned surface water is in essence river Rhine or Meuse water, the water quality in the five sources largely varies, because abstraction is almost never practised directly from the rivers. GWA treats water from the Loenderveen Lake, which is regularly replenished with Bethune polder drainage water (in the future to be mixed with AmsterdamRhine canal water at a ratio of 1:1). PWN and WRK treat water from the IJssel Lake, which is fed with water from river Rhine via one of its branches, the Ussel river. DZH practices dune infiltration of water abstracted from the Andels Meuse (a dammed arm of river Meuse, practically serving as a reservoir), and EWR of Rhineland polder drainage water. The purpose of their treatment also varies (drinking water, industrial water, water for dune infiltration, etc.) and so does the water treatment technology applied. Table 1.5 summarises the selected water quality management and treatment technology. 
Table 1.1 Year-average minimum and maximum water quality of surface water resources, based on average monthly measurements by the water enterprises.

\begin{tabular}{|c|c|c|c|c|c|}
\hline $\begin{array}{c}\text { Water } \\
\text { Quality } \\
\text { Parameter }\end{array}$ & $\begin{array}{c}\text { IJssel Lake } \\
\text { (Reservoir) } \\
\text { PWN } \\
\text { Andijk } \\
\text { 1984-89 }\end{array}$ & $\begin{array}{c}\text { IJssel Lake } \\
\text { Reservoir) } \\
\text { WRK } \\
\text { Andijk } \\
1986-92 \\
\end{array}$ & $\begin{array}{c}\text { Loenderveen } \\
\text { Lake } \\
\text { GWA } \\
\text { Amsterdam } \\
1986-92\end{array}$ & $\begin{array}{c}\text { Andels } \\
\text { Meuse } \\
\text { DZH } \\
\text { Den Haag } \\
1986-92 \\
\end{array}$ & $\begin{array}{c}\text { Polder } \\
\text { Water } \\
\text { EWR } \\
\text { Katwijk } \\
1989-92 \\
\end{array}$ \\
\hline Temperature $\quad{ }^{\circ} \mathrm{C}$ & $1.2-20.7$ & $1.4-20.3$ & $3.6-22.3$ & $1.8-22.4$ & $1.5-21.6$ \\
\hline $\mathrm{pH}$ & 7.9-9.45 & 7.7-8.9 & $7.5-8.4$ & 7.7-8.6 & 7.6-8.5 \\
\hline $\mathrm{PO}_{4}-\mathrm{O} \quad \mathrm{mgP} / \mathrm{L}$ & N.M. & $0.0077-0.095$ & $0-0.014$ & $0.006-0.063$ & $0.124-1.04$ \\
\hline $\mathrm{mgP} / \mathrm{L}$ & $0.06-0.76$ & $0.05-0.25$ & $0.007-0.04$ & $0.04-0.2$ & $0.39-1.15$ \\
\hline $\mathrm{NO}_{3}+\mathrm{NO}_{2} \mathrm{mgN} / \mathrm{L}$ & N.M. & $0.57-4.52$ & $0.42-1.44$ & $1.74-5.5$ & $1.1-6.6$ \\
\hline $\mathrm{mgN} / \mathrm{L}$ & $0.04-0.79$ & $0.04-0.9$ & $0.12-0.89$ & $0.08-0.55$ & $0.17-2.78$ \\
\hline $\mathrm{mgSi} / \mathrm{L}$ & N.M. & $0.05-2.8$ & $3.7-13.1$ & $0.25-5.6$ & $1.04-11$ \\
\hline $\mathrm{Chl} a$ & 8.6-198 & $6.5-101$ & $1.3-8.4$ & $1.6-37$ & $1.5-51$ \\
\hline$\mu \mathrm{g} / \mathrm{L}$ & $18-238$ & $13-132$ & $2.7-10.3$ & $2.6-58$ & N.M \\
\hline Algal Vol. $\mathrm{mm}^{3} / \mathrm{L}$ & $1.1-411$ & $0.4-97$ & N.M. & N.M. & N.M. \\
\hline
\end{tabular}
Chl $a$ :Chlorophyll- $a$
$\mathrm{PO}_{4} \mathrm{-o}$ : ortho phosphate
N.M.: not measured
Chl t :Chlorophyll-total
$\mathrm{PO}_{4} \mathrm{t}$ : total phosphate

During the collection and processing of the data, it appeared that the degree of attention paid to algae, as demonstrated by the frequency and diversity of algae related measurements, varies between the enterprises, and is proportional to the number of problems experienced in the past. The attention is determined, for example, by whether the end product is drinking, industrial or infiltration water. This inconsistency in the data set is compounded by the absence of a proper algae related standard for product water, and by the absence of a proper measuring technique that is able to include all types of algae in proportion to their actual concentrations.

Statistical analysis of the data related to comparison of the five water resources was performed. The aim of the two way analysis of variance (ANOVA) was to test the similarity between the (year-average) raw water quality of the five water resource localities, and to check whether the raw water quality of each of the water resources has changed within the analysed time period (see Table 1.1). The results show : (i) significant differences between the raw water quality at the five localities (raw water resources), and (ii) no significant changes of the water quality of each of the localities during the analysed periods. Based on a multiple range test, Table 1.2 reflects the similarities for the analysed water quality parameters at different localities. 
Table 1.2 Similarity of raw water quality between the five locations. a, b, c, d denote typical water quality categories, based on the two way ANOVA.

\begin{tabular}{|c|c|c|c|c|c|c|c|c|c|}
\hline Local & ${ }^{0} t$ & $\mathrm{pH}$ & $\mathrm{PO},-\mathrm{O}$ & $\mathrm{PO}_{-\mathrm{t}}$ & $\mathrm{NO}_{2+}$ & $\mathrm{NH}_{4}$ & $\mathrm{SiO}_{2}$ & Chl-a & Chl-t \\
\hline 1 & $a b$ & c & N.M. & c & N.M. & a & N.M. & c & c \\
\hline 2 & $\mathbf{a}$ & a & $\mathbf{a}$ & $\mathbf{a}$ & a & a & a & a & a \\
\hline 3 & $\mathbf{a}$ & b & a & b & b & $\mathbf{a}$ & $\mathbf{a}$ & b & b \\
\hline 4 & bc & $\mathbf{a}$ & b & d & b & b & c & $\mathbf{a b}$ & N.M. \\
\hline 5 & c & $\mathrm{ab}$ & $\mathbf{a}$ & b & b & a & b & $\mathrm{a}$ & \\
\hline
\end{tabular}

1 - PWN reservoir

2 - WRK III reservoir

N.M.: no measurements available for the locality
3 - DZH Andels Meuse

4 - EWR polder water

5 -GWA Loenderveen Lake

Chl $a: \quad$ Chlorophyll-a

Chl t: $\quad$ Chlorophyll-total

$\mathrm{NO}_{2+3}: \quad$ nitrites + nitrates

Multiple correlation analysis of the variables (analysed raw water quality parameters) for all the localities (raw water resources) shows high correlation coefficients between chlorophyll-tot on one hand and $\mathrm{pH}$, ortho- $\mathrm{PO}_{4}$, total $\mathrm{PO}_{4}, \mathrm{NO}_{2}+\mathrm{NO}_{3}$, and $\mathrm{SiO}_{2}$ on the other, and low correlation coefficients between chlorophyll-tot and ${ }^{\circ} \mathrm{t}$ and $\mathrm{NH}_{4}$ (Table 1.3). The lack of data for $\mathrm{SiO}_{2}$ for the polder water may explain to some extent the high negative correlation coefficient obtained.

Similar correlations were obtained for chlorophyll-a. Based on the maximum correlation coefficients, simple and multiple linear regression analyses were carried out, showing highest $r^{2}$ values for simple linear regression between $\log$ (chlorophyll-tot) and $\log \left(\mathrm{PO}_{4}-\mathrm{t}\right)\left[r^{2}=0.87\right]$, and for multiple linear regression between $\log ($ chlorophyll- $a), \log \left(\mathrm{PO}_{4}-\mathrm{t}\right)$ and $\mathrm{pH}\left[r^{2}=0.80\right]$. Fig. 1.2 represents a plot of the observed versus the predicted $\log$ (chlorophyll- $a$ ) values in function of the phosphate concentration and $\mathrm{pH}$. The transformation equation predicting the (chlorophyll-a) value on a year-average maximum basis is : $\mathrm{pr} \cdot \log ($ chlorophyll- $a$ ) $=0.52$ $\log \left(\mathrm{PO}_{4}-\mathrm{t}\right)+0.6(\mathrm{pH})-3.2$. The highest $r^{2}$ values for $\mathrm{PO}_{4}$-tot suggest that phosphorus is the key element which controls algae growth in surface water impoundments, consistent with the conclusions of Vollenweider [20] and also elaborated by many authors like Sakamoto [21], Dillon and Rigler [22], and Tillman et al. [23], for water impoundments under a range of conditions.

Table 1.3 Correlation coefficients $(r)$ and significance levels $(P)$ for correlation of $\log$ (chlorophyll-tot) with log values for different variables (except for $\mathrm{pH}$ which is a $\log$ value itself). Number of data $n=15$.

\begin{tabular}{||l|l|l|l|l|l|l|l|}
\hline Coef. & \multicolumn{1}{|c|}{${ }_{t}$} & \multicolumn{1}{c|}{$\mathrm{pH}$} & \multicolumn{1}{c|}{$\mathrm{PO}_{1}-\mathrm{o}$} & \multicolumn{1}{c|}{$\mathrm{PO}_{1}-\mathrm{t}$} & \multicolumn{1}{c|}{$\mathrm{NO}_{2+3}$} & \multicolumn{1}{c|}{$\mathrm{NH}_{1}$} & $\mathrm{SiO}_{2}$ \\
\hline$r$ & 0.11 & 0.76 & 0.96 & 0.93 & 0.81 & -0.09 & -0.8 \\
\hline$P$ & 0.7 & 0.0011 & 0.0000 & 0.0000 & 0.0002 & 0.75 & 0.0003 \\
\hline
\end{tabular}




\section{pr.log $(\mathrm{chl}-\mathrm{a})=0.62 \log (\mathrm{PO} 4-\mathrm{t})+0.6(\mathrm{pH})-3.2$}

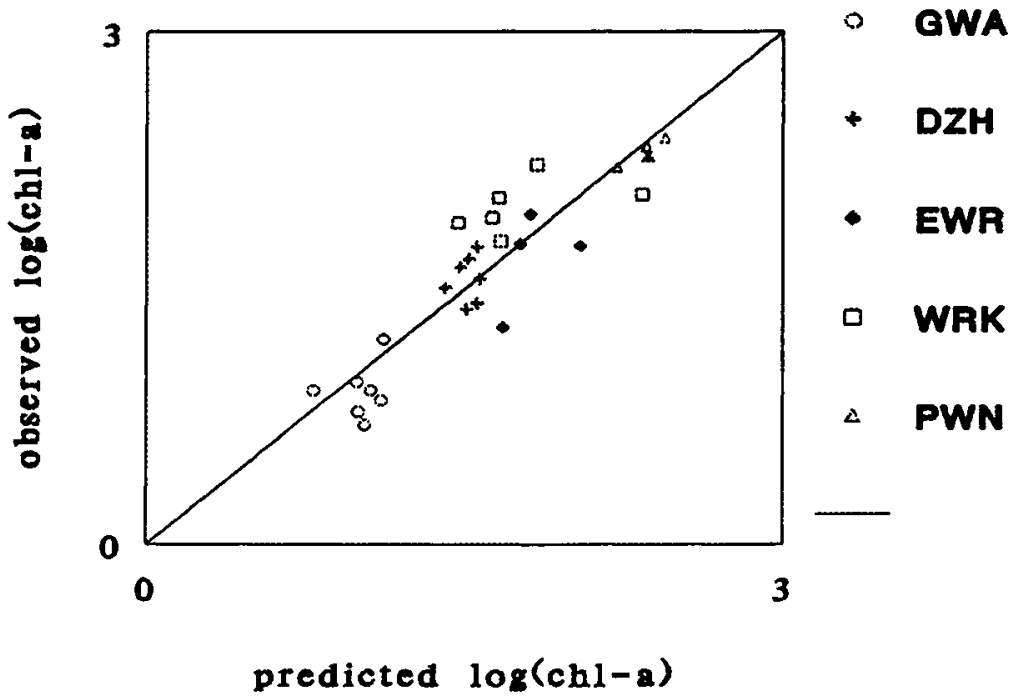

Fig. 1.2 Observed versus predicted $\log ($ chlorophyll $-a)$ values, $r^{2}=0.8$.

The reservoirs' chlorophyll and phosphorus data were superimposed on a graph by Harris [24] (based on results for a combination of lakes analysed by Janus and Vollenweider, and a number of oligotrophic Canadian lakes); the results fall in the $95 \%$ confidence limit of the regression line (Fig.1.3).

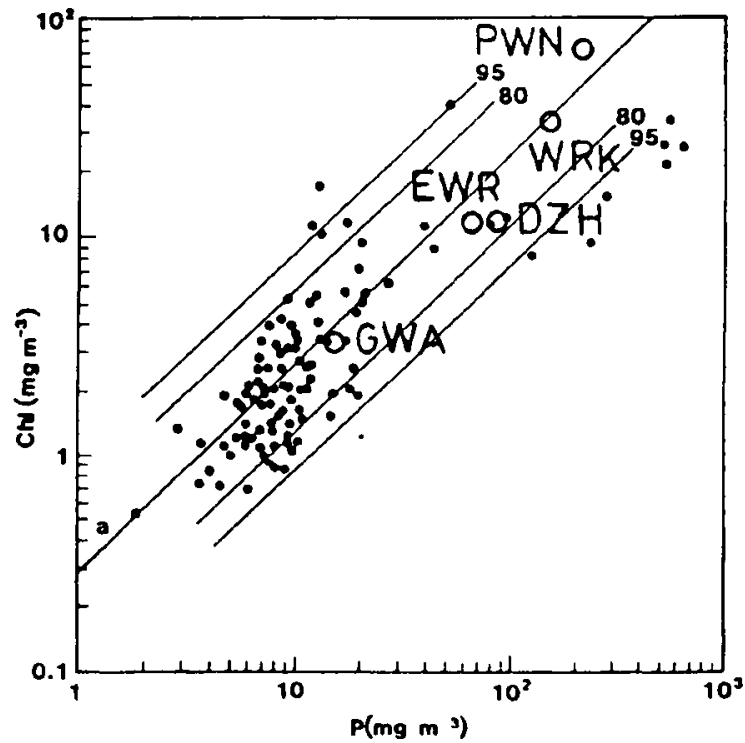

Fig. 1.3 Annual mean chlorophyll vs. P concentrations for the five impoundments, superimposed on a graph from Harris [23]. 
The close relation between chlorophyll- $a$ and phosphorus, emerging from the multiple regression analysis, suggests causality and is again in accordance with Vollenweiders results. However, the causal relation between chlorophyll- $a$ and $\mathrm{pH}$ is more complex. Although high correlation coefficients do not automatically imply the presence of causal relations, the causal relation between chlorophyll- $a$ and $\mathrm{pH}$ may be supported by the $\mathrm{CO}_{2} / \mathrm{pH}$ relation hypothesis. Indeed, the relatively high $\mathrm{pH}$ of the five impoundments ( $\mathrm{pH} 7.5-9.45$ on year average basis) favours the growth of cyanobacteria at high eutrophication levels [25], as recorded in our case [19]. In addition it may be hypothesized that a feedback mechanism exists between chlorophyll, $\mathrm{PO}_{4}$ and $\mathrm{pH}$, in the sense that resuspension of phosphorus from reservoir sediments occurs under the recorded high $\mathrm{pH}$ conditions, which supports further algae growth $[26,27]$.

The intensive photosynthetic activity of high biomass concentrations further shifts $\mathrm{pH}$ to high values, possibly to the point where $\mathrm{C}$ becomes a limiting factor. As cyanobacteria have lower saturation constants $\mathrm{K}_{\mathrm{m}}$ for uptake of total carbon and $\mathrm{CO}_{2}$, this condition combined with the high $\mathrm{pH}$ promotes cyanobacteria dominance [25].

Summaries of the observations on the most significant species encountered in the five impoundments describing their characteristics and treatability, are presented in Table 1.4. The treatability of the algae species, i.e. the extent of their removal in water treatment, is mainly affected by (i) the treatment technology applied, (ii) optimization of the applied treatment technology, and (iii) characteristics of the algal species involved. Although the choice of the treatment technology rarely is made on the basis of efficient algae removal alone, the occurrence of the periodical algae blooms plays an important role. Under normal circumstances (moderate algae concentrations) algae can be removed more or less efficiently by commonly applied treatment technologies.

However, this technology is not necessarily optimal for the removal of all the algae species concurrently or separately (at other time periods) present in the water. The algae characteristics and properties influence their removal, including size, shape, cell surface characteristics (composition of algal cell wall and resultant colloidal surface charge characteristics), excretion of EOM and motility. Many of these characteristics vary with algae age, as well as within subspecies, limiting the removal predictability. In this light, the terms 'Problematic', 'Good', etc. treatability of Table 1.4 are only indicative. They are used to characterize the general degree of problems related to a particular algal species removal, the effect on effluent water quality, and the water production costs.

Each of the studied water impoundments is characterised by seasonal (yearly) variations. Algal blooms are common during certain periods of the year, but they are proportional to the degree of eutrophication and most acute in the cases of WRK (Figs. 1.4 and 1.5) and PWN treating IJssel Lake water. A pronounced seasonal occurrence of cyanobacteria (especially $M$. aeruginosa) is found in all five water resources, again showing proportionality between concentration and the degree of eutrophication. This was found to be most typical in Loenderveen Lake. While diatoms are characterised as superior competitors under phosphorus limitation (high N/P ratio) and water temperature below $14^{\circ} \mathrm{C}$, green algae and cyanobacteria are dominant under nitrogen limitation (low N/P and Si/P ratios) and high temperatures [23]. 
Table 1.4 The most significant algae species encountered in the five impoundments, indicating their basic characteristics and treatability.

\begin{tabular}{|c|c|c|c|}
\hline $\begin{array}{l}\text { Algse species and uxonomy } \\
\text { Location Trealment plant }\end{array}$ & Fitgurative representation & Characteristics & Treatability \\
\hline $\begin{array}{l}\text { Melosira spp. } \\
\text { (Diatomeae) } \\
\text { 1. 4.5. } \\
\end{array}$ & & $\begin{array}{l}\text { Porous, capsule like, cylindrical cells forming } \\
\text { filaments; blooms; } L=10-40 \mu \mathrm{m} ; W=5-20 \mu \mathrm{m} \text {. }\end{array}$ & Problematic \\
\hline $\begin{array}{l}\text { Stephanodiscus spp. } \\
\text { (Diatomeae) } \\
\text { 1.2.4. }\end{array}$ & & $\begin{array}{l}\text { Single, porous cells, spines at edges; in hard } \\
\text { waters or basic lakes; } L=8-20 \mu \mathrm{m} \text {. }\end{array}$ & Problematic \\
\hline $\begin{array}{l}\text { Asterionella spp. } \\
\text { (Diatomeae) } \\
\text { 1. } 3 \text {. }\end{array}$ & & $\begin{array}{l}\text { Often very abundant, spoke like arrangement } \\
\text { of rectangular frustules; in hard waters; } L=40 \\
130 \mu \mathrm{m} ; \mathrm{W}=2 \mu \mathrm{m} \text {. }\end{array}$ & $\begin{array}{l}\text { Moderately } \\
\text { problematic }\end{array}$ \\
\hline $\begin{array}{l}\text { Nitzschia spp. } \\
\text { (Diatomeae) } \\
\text { 3. }\end{array}$ & & $\begin{array}{l}\text { Commonly solitary frustules, tapered at ends, } \\
\text { straight or sigmoid, porous; } L=25-110 \mu \mathrm{m} ; \\
\mathrm{W}=5-10 \mu \mathrm{m} \text {. }\end{array}$ & $\begin{array}{l}\text { Moderately } \\
\text { problematic }\end{array}$ \\
\hline $\begin{array}{l}\mu \text {-algae } \\
\text { (Diatomeae) } \\
3 \text {. }\end{array}$ & 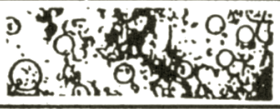 & $\begin{array}{l}\text { Small capsule like cylindrical cells, very much } \\
\text { like Stephanodiscus hantzscshii. }\end{array}$ & Problematic \\
\hline $\begin{array}{l}\text { Microcystis spp. } \\
\text { (Cyanophyta) } \\
\text { 1.2.3.4.5. } \\
\end{array}$ & & $\begin{array}{l}\text { Irregularly shaped colonies of thousands of } \\
\text { sphere cells, also single cells; gas vacuoles } \\
\left(\mathrm{N}_{2}\right) \text {;extensive blooms-surface mat; } \mathrm{D}=3-7 \mu \mathrm{m} \text {. }\end{array}$ & Problematic \\
\hline $\begin{array}{l}\text { Oscillatoria spp. } \\
\text { (Cyanophyta) } \\
\text { 1.2.3.4. } \\
\end{array}$ & & $\begin{array}{l}\text { Cells forming filaments - solitary or } \\
\text { intermingled, cells lack definite sheath; } \\
\text { blooms; } \mathrm{L}=2-4 \mu \mathrm{m},(\mathrm{L}=100 \mu \mathrm{m}) ; \mathrm{W}=3-5 \mu \mathrm{m} \text {. }\end{array}$ & Problematic \\
\hline $\begin{array}{l}\text { Aphanizomenon spp. } \\
\text { (Cyanophyta) } \\
4 .\end{array}$ & zis & $\begin{array}{l}\text { Cells forming filamentous bundles, heterocysts } \\
\text { present; blooms; } \mathrm{L}=5-15 \mu \mathrm{m},\left(\mathrm{L}_{4}=150 \mu \mathrm{m}\right) \\
\mathrm{W}=5-6 \mu \mathrm{m} \text {. }\end{array}$ & Problematic \\
\hline $\begin{array}{l}\text { Anabaena spp. } \\
\text { (Cyanophyta) } \\
3 .\end{array}$ & $\infty$ & $\begin{array}{l}\text { Cells forming filaments, heterocysts present; } \\
\text { upper layers; blooms - surface mats; } L=6-8 \\
\mu \mathrm{m},(L=30-35 \mu \mathrm{m}) ; \mathrm{W}=6 \mu \mathrm{m} \text {. }\end{array}$ & $\begin{array}{l}\text { Moderately } \\
\text { problematic }\end{array}$ \\
\hline $\begin{array}{l}\text { Scenedesmus spp. } \\
\text { (Chlorophyta) } \\
4 .\end{array}$ & & $\begin{array}{l}4,8 \text { or } 12 \text { oval or fusiform cells forming } \\
\text { colonies, } 1 \text { or } 2 \text { spines at end cells; } L=10-15 \\
\mu \mathrm{m}\end{array}$ & $\begin{array}{l}\text { Moderately } \\
\text { good }\end{array}$ \\
\hline $\begin{array}{l}\text { Coelastrum spp. } \\
\text { (Chlorophyta) } \\
\text { 1. } 4 .\end{array}$ & & $\begin{array}{l}\text { Spherical or polygonal cells forming hollow } \\
\text { colonies, by protuberances from mucilaginous } \\
\text { sheaths; } D=8-12 \mu \mathrm{m} \text {. }\end{array}$ & $\begin{array}{l}\text { Moderately } \\
\text { good }\end{array}$ \\
\hline $\begin{array}{l}\text { Oocystis spp. } \\
\text { (Chlorophyta) } \\
1 .\end{array}$ & & $\begin{array}{l}\text { Elliptic or lemon shaped, one or more } \\
\text { generations of mother cell walls enclose } \\
\text { daughter cells; } L=14-26 \mu \mathrm{m} ; \mathrm{W}=10-20 \mu \mathrm{m} \text {. }\end{array}$ & Good \\
\hline $\begin{array}{l}\text { Cryptophyceae spp. } \\
\text { 1.3.5. }\end{array}$ & & $\begin{array}{l}\text { Solitary cells, rarely colonial, protozoan like, } 2 \\
\text { flagella, chloroplast pigments - brown, blue or } \\
\text { red. }\end{array}$ & $\begin{array}{l}\text { Moderately } \\
\text { problematic }\end{array}$ \\
\hline $\begin{array}{l}\text { Chrysophyceae spp. } \\
\text { 3. } 5 \text {. }\end{array}$ & to. & $\begin{array}{l}\text { Unicellular or colonial, rarely filamentous, } \\
\text { chloroplast pigments - yellow, brown, golden } \\
\text { brown, thick wall, } 1 \text { or } 2 \text { flagella, motile. }\end{array}$ & $\begin{array}{l}\text { Moderately } \\
\text { problematic }\end{array}$ \\
\hline
\end{tabular}

\section{1.- PWN reservoir}

4.- WRK III reservoir

L - cell length

\section{3.- GWA Loenderveen Lake;}

2.- EWR polder water

$L_{4}$ - total length of filament
W - cell width

D - cell diameter

Comment : The morphology of different algal species asserts the need of different algae counting procedures. Microcystis aeruginosa is counted as single cells and as colonies. Bundles of filamentous species most often disintegrate during the preparation of the ample; an attempt is made to count all the algae that may form such bundle atructures. Scenedesmus app. of 8 or 12 cells are counted as 2 or 3 Scenedesmus entities. Similarly other disinlegrated colonial species are counted as separate entilies. 


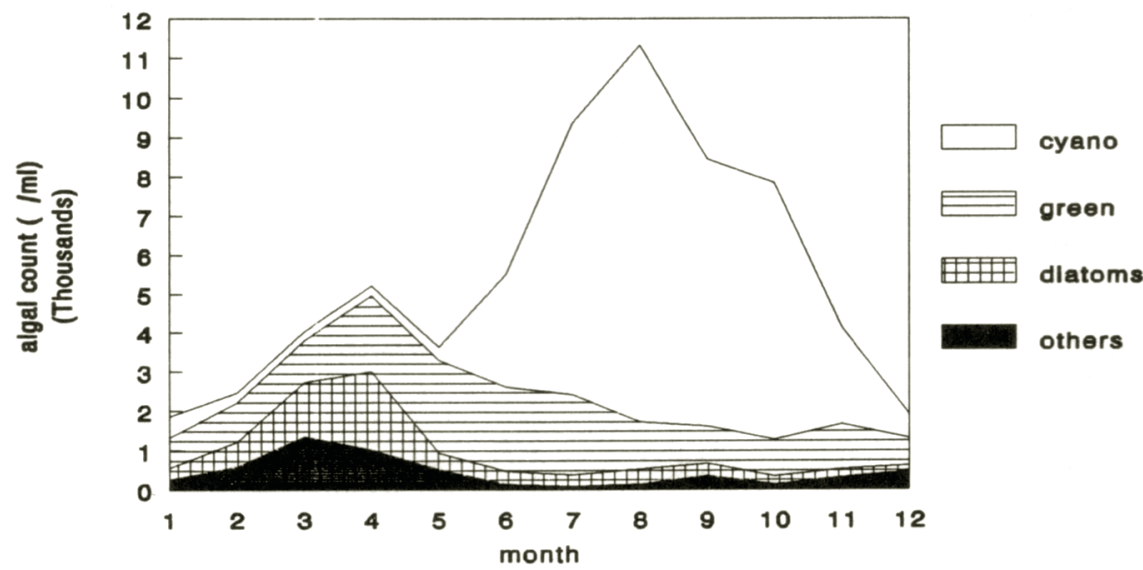

Fig. 1.4 Average monthly algal count for the WRK III reservoir (integrated over the total reservoir depth of $20 \mathrm{~m}$ ), for different algal taxa in the period 1988-92.

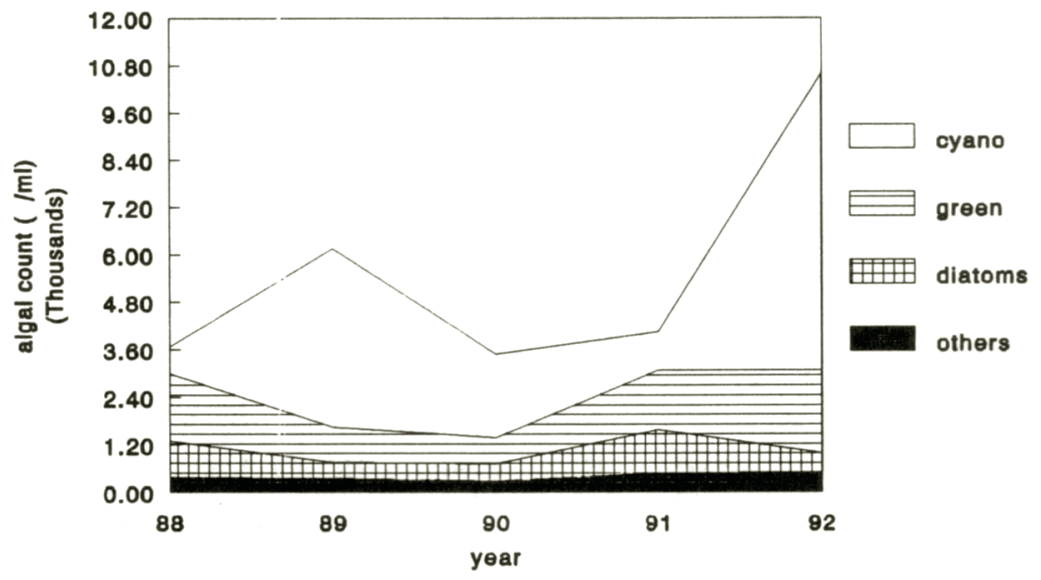

Fig. 1.5 Average yearly algae count for different taxa in the WRK III reservoir for the period 1988-92.

Reservoir management involving chemicals application (affecting nutrients availability, pH, etc.) and water mixing within the reservoir, as well as climatic conditions, influence the phytoplankton composition as for example in the PWN and WRK reservoirs where higher 
concentrations of Oscillatoria spp. were found in the period of 1990-92. This is consistent with other experiences under Dutch climatic circumstances [25]. This suggests that the current raw water quality criteria are insufficient to avoid prolonged cyanobacteria blooms. Cyanobacterial dominance refers to a high biomass concentration, which is correlated (indirectly) to the nutrient level. This is the case in particular with Oscillatoria spp., while for Microcystis spp. it is the limiting nutrient that most likely will determine the magnitude of its bloom.

\subsection{DISCUSSION}

\subsubsection{Algae and water treatment - problems and remedies}

\subsection{1.a Reservoir management}

To cope with algae efficiently requires a combination of detailed water quality monitoring, reservoir water quality management, and water treatment measures. Appropriate and especially well timed microbiological analysis (i.e. done immediately after sampling and not postponed for weeks, which often is the practice), accompanied with other physio-chemical analysis provides a better tool for prediction of algae concentration and species variations. Although treatment plant operators are found to be increasingly aware of the importance of the prediction capacity, it often is neglected or insufficiently addressed. Delays between sampling and analysis typically result in poor treatment process operation. On the other hand, it is generally very effective to reduce the algal load ahead of the treatment through reservoir water quality management and pretreatment as it appears that no treatment step on its own is able to ensure adequate removal rates. A range of reservoir management techniques are applied in this context with varying degrees of success: phosphorus removal (either by precipitation with coagulant, or by diverting phosphorus contributing flows), artificial destratification by mixing of the water column, use of algicides (mainly copper sulphate), sonic disruption of algal cells, suction dredging, and aeration of the hypolimnetic layer [4]. Reservoir management significantly diminishes the algae load, but the appropriate approach is reservoir and algae specific.

The successful application of better reservoir design is the case presented in Fig. 1.6. The use of the shallow $3 \mathrm{~m}$ deep PWN reservoir was temporarily supplemented by the $20 \mathrm{~m}$ deep WRK III reservoir, resulting in drastic reduction of the exposure to sun-light and subsequent poor algae growth. Examples of successful pre-treatment include the coagulation with ferrous sulphate and settling of water entering the water reservoir of GWA, the application of ferrous sulphate in Andels Meuse by DZH and in the WRK III reservoir (which also includes periodical mixing of the water column). On the other hand, such measures have also been reported to yield adverse effects. In the Wahnbachtalsperrenverband in Siegburg, Germany, phosphorus reduction in the raw water reservoirs led to a rapid increase in diatom level at the expense of other algae, and resulted in poorer overall treatment performance during periods of their blooms. 


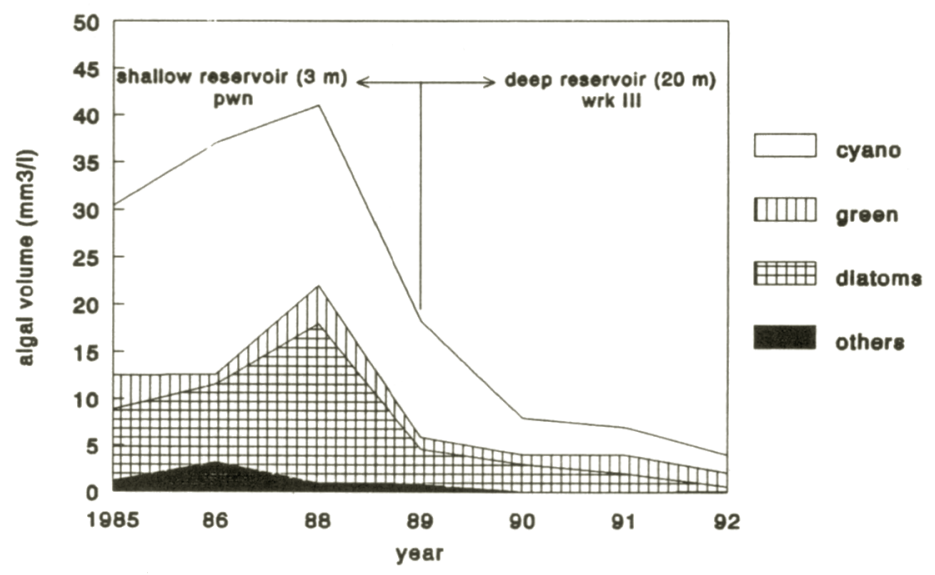

Fig. 1.6 Average algal volume for different taxa in the reservoirs of PWN (3 m deep) and WRK III (20 m deep), (1987 data unavailable).

\subsection{1.b Treatment process}

Cyanobacteria and in particular Microcystis spp. and Oscillatoria spp. are known to pass readily through treatment and end up in drinking water in relatively large numbers. A critical feature of the Microcystis spp. is their ability to form colonies, as well as to exist in a single cell form, whilst Oscillatoria spp. can exist as solitary or intermingled filaments. Small algae pass through filters more readily than larger ones so that when blooms of small algae, such as Microcystis spp. occur, their counts in treated water are high especially towards the end of the bloom period when colonies disintegrate naturally, or as a consequence of algicides. Up to $5.3 \times 10^{4}$ cells $/ \mathrm{mL}$ of the former and $4.5 \times 10^{4}$ cells $/ \mathrm{mL}$ of the latter species have been recorded by the Severn Trent Water Authority in 1985 and 1986 in the United Kingdom, for filtered water [4]. Microcystis spp. cells can rupture and leak intra-cellular substances during turbulent aqueduct transport from the reservoir to the treatment site (rupture rate between 61-72\%) [28]. Similar rupture and colony break-up may be expected during initial pumping stages in water treatment plants, representative for Dutch operation circumstances. In other words, water treatment plant design may in itself aggravate the algae related problems.

In general, the treatment approach in the studied plants is complex and aims at the overall removal optimization of different pollutants, including suspended solids, dissolved and colloidal matter, organic micropollutants, heavy metals, algae, etc.; this varies depending on the raw water source as well as the final product user (Table 1.5). Coagulation and flocculation, and rapid sand filtration are applied in all plants, while granular activated carbon filtration is used in three cases (GWA, WRK and PWN). Dissolved air flotation is applied at DZH and EWR, while sedimentation is practised at WRK III and PWN. Slow sand filtration is practised only at the GWA. 
Table 1.5 The treatment processes in the five studied treatment plants.

\begin{tabular}{|c|c|c|c|c|c|}
\hline $\begin{array}{l}\text { MANAGEMENT } \\
\text { \&TREATMENT } \\
\text { TECHNOLOGY } \\
\text { APPLIED }\end{array}$ & $\begin{array}{c}\text { GWA } \\
30 \mathrm{Mm}^{3} / \mathrm{y} \\
\text { Weesperkarspel }\end{array}$ & $\begin{array}{c}\text { WRK III } \\
110 \mathrm{Mm}^{3 / y} \\
\text { Prinses Juliana }\end{array}$ & $\begin{array}{l}\text { PWN } \\
35 \mathrm{Mm}^{3} / \mathrm{y} \\
\text { Andijk }\end{array}$ & $\begin{array}{c}\text { DZH } \\
70 \mathrm{Mm}^{3 / / y} \\
\text { Bergambacht + } \\
\text { Scheveningen }\end{array}$ & $\begin{array}{l}\text { EWR } \\
15 \mathrm{Mm}^{3 / y} \\
\text { Lindenbergh }\end{array}$ \\
\hline pre-coagulation & \#\#\# & $\# \#$ & & $\# \#$ & \\
\hline pre-settling & $\# \#$ & & & $\# \# \#$ & \\
\hline reservoir & $\# \#$ & \#\#\# & $\# \# \#$ & \#\#\# & \\
\hline reservoir mixing & & $\# \#$ & & & \\
\hline pre-filtration & \#\#\# & & & \#\#\# & \\
\hline straining $35 \mu \mathrm{m}$ & & & $\# \#$ & & \\
\hline sieves $200 \mu \mathrm{m}$ & & $\# \# \#$ & & & \\
\hline pre-chlorination & & \#P\# & \#\#\# & & \\
\hline transport $\mathrm{Cl}_{2}$ & & & & \#P\# & \\
\hline ozone & \#\#\# & & & & \\
\hline softening & $\# \#$ & & & & \\
\hline $\begin{array}{l}\text { coagulation/ } \\
\text { flocculation }\end{array}$ & ooo & $\# \#$ & $\# \# \#$ & \#\#\# & \#\# \\
\hline sedimentation & 000 & $\# \#$ & $\# \#$ & & \\
\hline flotation (DAF) & & & & $\# \# \#$ & $\# \#$ \\
\hline rapid sand filters & 000 & \#\#\# & $\# \# \#$ & $\# \#$ & $\# \#$ \\
\hline activated carbon & \#o\# & $\# \# \#$ & $\# \#$ & & \\
\hline slow sand filters & \#\#\# & & & & \\
\hline straining $30 \mu \mathrm{m}$ & & & $\# \# \#$ & & \\
\hline post-chlorination & $\# \mathrm{P \#}$ & & & & \\
\hline $\mathrm{ClO}$, disinfection & & & $\# \# \#$ & & \\
\hline
\end{tabular}

\#\#\# - PRESENTLY IN OPERATION "P" - PERIODICALLY APPLIED
DOO - PREVIOUSLY IN OPERATION

\#O\# - REPLACED WITH (IN OPERATION NOW)

Algal blooms and typically those of cyanobacteria, pose the most serious treatment problems. These include : (i) interference with the coagulation and flocculation process, (ii) increased disinfectant demand, (iii) trihalomethane production, (iv) frequent filter blocking, and (v) increased use of backwash water (Table 1.6). This translates into higher production cost. Process modifications to address these problems can also be expensive or have side effects. As no algae standards or objectives exist, water companies tend to deal with the problem on the basis of 'as much as possible' removal, within the technological context and production cost bracket that is considered commonly acceptable. This approach is usually indiscriminatory and poorly focused. Local guide levels exist such as those at the Wahnbachtalsperrenverband in Siegburg, Germany [29], $(0.1 \mu \mathrm{g} / \mathrm{L}$ chlorophyll- $a$ in treated water). 
Table 1.6 Present and anticipated situation in the five studied Dutch water enterprises. Most significant alga species encountered, related treatment and distribution problems, and remedies (illustrations from [30], except for GWA photo material of $\mu$-algae deposits on GAC filter).

\begin{tabular}{|c|c|c|c|c|}
\hline $\begin{array}{l}\text { Company } \\
\text { ( } \% \text { prod, } \\
\text { of total } \\
\text { surf. water } \\
\text { in NI) }\end{array}$ & $\begin{array}{l}\text { Rav water } \\
\text { source, treatment } \\
\text { plant end process }\end{array}$ & $\begin{array}{l}\text { Characteristic } \\
\text { algal species } \\
\text { in water resources }\end{array}$ & 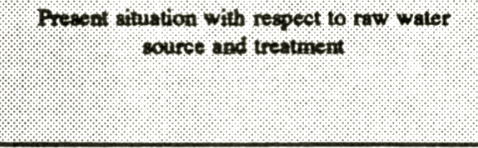 & Anticipated development \\
\hline $\begin{array}{l}\text { PWN } \\
(8 \%)\end{array}$ & $\begin{array}{l}\text { Ussel Lake-Andijk } \\
\text {-Straining } 35 \mu \mathrm{m} \\
-\mathrm{Cl}_{2}-6 \mathrm{~g}^{3} / \mathrm{m}^{3} \\
-\mathrm{FeClSO}_{4}-16 \mathrm{~g} / \mathrm{m}^{3} \\
-\mathrm{Ca}(\mathrm{OH})_{2}-30.5 \mathrm{~g} / \mathrm{m}^{3} \\
-\mathrm{Polyelect} .-0.5 \mathrm{~g} / \mathrm{m}^{3} \\
-\mathrm{SED}, \mathrm{v}=3.5 \mathrm{~m} / \mathrm{h} \\
-\mathrm{RSF}, \mathrm{v}=10 \mathrm{~m} / \mathrm{h} \\
-\mathrm{GAC}, \mathrm{v}=13.5 \mathrm{~m} / \mathrm{h} \\
-\mathrm{Straining} 35 \mu \mathrm{m} \\
-\mathrm{ClO}\end{array}$ & $\begin{array}{l}\text { Microcystis spp. (Cyanophyta) } \\
\text { Oscillatoria spp. } \\
\text { Melosira spp. (Diatomeae) } \\
\text { Stephanodiscus spp. } \\
\text { Asterionella spp. } \\
\text { Coelastrum spp.(Chlorophyta) } \\
\text { Oocystis spp. } \\
\text { Cryptophyceae spp. }\end{array}$ & $\begin{array}{l}\text { Serious current operational difficulties: } \\
100 \% \text { coagulant and coagulant aid dose } \\
\text { increase (up to } 40 \mathrm{mg} / 1 \mathrm{Fe}^{3+} \text { and } 1.0 \mathrm{mg} / 1 \\
\text { polyelectrolyte) } \\
\text { trihalomethane formation } \\
\text { increased backwash water quantity } \\
\text { algae passing through treatment }\end{array}$ & $\begin{array}{l}\text { In long term only } \\
\text { partial improvement of } \\
\text { present eutrophication of } \\
\text { raw water resource } \\
\text { expected } \\
\text { Partial improvement } \\
\text { of situation due to } \\
\text { deepening of reservoir } \\
\text { before treatment }\end{array}$ \\
\hline $\begin{array}{l}\text { WRK } \\
(25 \%)\end{array}$ & $\begin{array}{l}\text { Ussel Lake-Princess } \\
\text { Juliana, Andijk } \\
\text {-Screens } 200 \mu \mathrm{m} \\
-\mathrm{Fe}_{2}\left(\mathrm{SO}_{\mathcal{J}_{3}}-20 \mathrm{~g} / \mathrm{m}^{3}\right. \\
-\mathrm{Polyelect.}-0.2 \mathrm{~g} / \mathrm{m}^{3} \\
-\mathrm{Ca}(\mathrm{OH})_{2} \\
-\mathrm{SED} \text { (lamella) } \\
\text {-RSF, } \mathrm{v}=10 \mathrm{~m} / \mathrm{h} \\
\text {-GAC (partial) }\end{array}$ & $\begin{array}{l}\text { Microcystis spp. (Cyanophyta) } \\
\text { Oscillatoria spp. } \\
\text { Aphanizomenon spp. } \\
\text { Melosira spp. (Diatomeae) } \\
\text { Stephanodiscus spp. } \\
\text { Coelastrum spp.(Chlorophyta) } \\
\text { Scenedesmus spp. }\end{array}$ & $\begin{array}{l}\text { Serious current operational difficulties: } \\
100 \% \text { coagulant and coagulant aid dose } \\
\text { increase (up to } 40 \mathrm{~g} / \mathrm{m}^{3} \mathrm{Fe}^{3+} \text { and } 1.0 \mathrm{~g} / \mathrm{m}^{3} \\
\text { polyelectrolyte) } \\
\text { trihalomethanes formation } \\
\text { increased backwash water quantity } \\
\text { algae passing through treatment } \\
\text { increased MFI and AOC values and possible } \\
\text { infiltration wells clogging }\end{array}$ & $\begin{array}{l}\text { In long term only } \\
\text { partial improvement of } \\
\text { present eutrophication of } \\
\text { raw water resource } \\
\text { expected } \\
\text { Partial improvement } \\
\text { of situation due to } \\
\text { mixing and coagulant } \\
\text { application in reservoir }\end{array}$ \\
\hline $\begin{array}{l}\text { GWA } \\
(7 \%)\end{array}$ & $\begin{array}{l}\text { Loenderveen Lake- } \\
\text { Weesperkarspel } \\
\text {-Ozone - 2-5 g/m' } \\
\text {-Softening } \\
\text {-FeCl, (1992) } \\
\text {-Polyelect.-(1992) } \\
\text {-SED(lamella, 1992) } \\
\text {-PAC (1992) } \\
\text {-RSF (1992) } \\
\text {-GAC } \\
\text {-SSF }\end{array}$ & $\begin{array}{l}\text { Microcystis spp. (Cyanophyta) } \\
\text { Oscillatoria spp. } \\
\text { Anabaena spp. } \\
\text { Nitzschia spp. (Diatomeae) } \\
\text { Asterionella spp. } \\
\mu \text { - algae } \\
\text { Cryptophyceae spp. } \\
\text { Chrysophyceae spp. }\end{array}$ & $\begin{array}{l}\text { Operational difficulties: } \\
\text { surface clogging of GAC filters by phyto- } \\
\text { and zooplankton cake layer }\end{array}$ & $\begin{array}{l}\text { New surface water } \\
\text { source of inferior quality } \\
\text { (contributing to } \\
\text { eutrophication) to be } \\
\text { used to double } \\
\text { production capacity } \\
\text { Reduction of algae } \\
\text { load over GAC filters } \\
\text { due to: } \\
\text {-direct filtration mode of } \\
\text { filtration plant at intake } \\
\left.\text { (1-3 } \mathrm{g} \mathrm{Fe}^{3+} / \mathrm{m}^{3}\right) \\
\text {-reduced ozone doses at } \\
\text { beginning of process }\end{array}$ \\
\hline $\begin{array}{l}\text { DZH } \\
(16 \%)\end{array}$ & $\begin{array}{l}\text { Andels Meuse- } \\
\text { Bergambacht }+ \\
\text { Scheveningen } \\
\text {-RSF } \\
-\mathrm{PAC}-2-4 \mathrm{~g} / \mathrm{m}^{3} \text { or } \\
-\mathrm{AL}_{2}\left(\mathrm{SO}_{3}-4-6 \mathrm{~g} / \mathrm{m}^{3}\right. \\
-\mathrm{DAF}, \mathrm{t}=7-14 \mathrm{~min} \\
-\mathrm{RSF}, \mathrm{v}=10 \mathrm{~m} / \mathrm{h}\end{array}$ & $\begin{array}{l}\text { Microcystis spp. (Cyanophyta) } \\
\text { Melosira spp. (Diatomeae) } \\
\text { Cryptophyceae spp. } \\
\text { Chrysophyceae spp. } \\
\\
\text { Pind }\end{array}$ & $\begin{array}{l}\text { Operational difficulties: } \\
\text { algae and cellular products passing through } \\
\text { treatment } \\
\text { increased AOC values, resulting in reduced } \\
\text { pipe flow due to increased } \mathbf{k} \text {-values of pipes }\end{array}$ & $\begin{array}{l}\text { Unchanged situation as } \\
\text { long as application of } \\
\text { phosphate precipitation } \\
\text { in Andels Meuse is } \\
\text { allowed } \\
\text { New direct filtration } \\
\text { plant for algae removal } \\
\text { in Brakel under } \\
\text { investigation }\end{array}$ \\
\hline $\begin{array}{l}\text { EWR } \\
(3 \%)\end{array}$ & $\begin{array}{l}\text { Rhineland polder } \\
\text { water- Lindenbergh } \\
\text {-FeCISO }-8 \mathrm{~g} / \mathrm{m}^{3} \\
\text {-DAF, } t=15 \mathrm{~min} \\
\text {-RSF, } \mathrm{v}=5 \mathrm{~m} / \mathrm{h} \\
\end{array}$ & $\begin{array}{l}\text { Microcystis spp. (Cyanophyta) } \\
\text { Oscillatoria spp. } \\
\text { Stephanodiscus spp. (Diatomeae) }\end{array}$ & $\begin{array}{l}\text { Product water quality problems: } \\
\text { algae passing through treatment in large } \\
\text { quantities, especially during periodical blooms }\end{array}$ & $\begin{array}{l}\text { Complete change of } \\
\text { present raw water source } \\
\text { with one of better } \\
\text { quality, possibly Andels } \\
\text { Meuse }\end{array}$ \\
\hline
\end{tabular}


Nevertheless, their implementation on a wider scale and at different circumstances is not always feasible. It has been argued that the discussed chlorophyll- $a$ guide level is too stringent in view of the very low assimilable organic carbon (AOC) value associated with it [31]. Namely, the proposed $0.1 \mu \mathrm{g} / \mathrm{L}$ chlorophyll- $a$ guideline value should imply $3 \mu \mathrm{g} / \mathrm{L} \mathrm{AOC \text {, }}$ which is lower than the already ambitious recommended $10 \mu \mathrm{g} / \mathrm{L}$ AOC required for biologically stable water (proposed by van der Kooij [32]).

Research in the past two decades was mostly directed at optimising conventional treatment processes, commonly centred around sedimentation and filtration. Agglomeration (coagulation/flocculation) has received the largest attention, as it is the prerequisite for any efficient particles (and algae) removal regardless of the subsequent down-stream removal process (sedimentation, flotation or filtration). Efficient water conditioning with the purpose of improving the coagulation/flocculation process was approached in a similar manner. However, it was soon realised that it is typically impossible to achieve adequate algae removal when they are present in concentrations that are typical for some eutrophic reservoirs (periodically up to $10^{5}-10^{6}$ cells $/ \mathrm{mL}$ ). Obtained removal rates strongly depend on prevailing plankton type and range from 50-99.9\%. However, even a rate of $99.9 \%$ removal can still be inadequate for raw water of such poor quality [29].

\subsubsection{Dissolved air flotation (DAF) - a viable solution option}

Because of the natural tendency of algae to float dissolved air flotation (DAF) attracts attention as a (pre)treatment option prior to final filtration. Because DAF requires a preceding particle agglomeration (coagulation/flocculation) step, it performs equally well as common flocculation/sedimentation with respect to DOC, UV, true colour and trihalomethane precursor removal $[33,34]$. On the other hand DAF tends to be more efficient than sedimentation for removal of turbidity and particulates formed by coagulation [35]. Experience from newly built flotation facilities for drinking water treatment (e.g. Birmingham Frankley, UK; Millwood New Castle, USA; Pietarsaari, Finland), and from adapted existing plants, where e.g. sedimentation was replaced by flotation followed by rapid sand filtration document this [36, 37]. It is generally confirmed that algal removal efficiency can be substantially enhanced by flocculation and flotation upstream of the final filtration. The same applies for algae conditioning, i.e. bringing the algae into a state which results in their more efficient downstream process removal, by application of oxidants, e.g. ozone [38], or $\mathrm{KMnO}_{4}$ [39].

Janssens [40] has proposed a tentative diagram to be used for process selection based on raw water turbidity and algal content (Fig.1.7). If all other quality requirements are fulfilled regarding DOC, hardness, colour, etc., flotation is the best available (pre)treatment technology for treatment of raw water with chlorophyll- $a$ values of typically $>10 \mu \mathrm{g} / \mathrm{L}$. This is the case in all of the five studied companies for shorter or longer periods of the year (Table 1.1). In addition, under the Dutch circumstances the occurrence of $M$. aeruginosa (Table 1.4) favours use of DAF, because this species is characterised by buoyancy [3], which renders them more susceptible to removal by the rising air bubbles in DAF. 


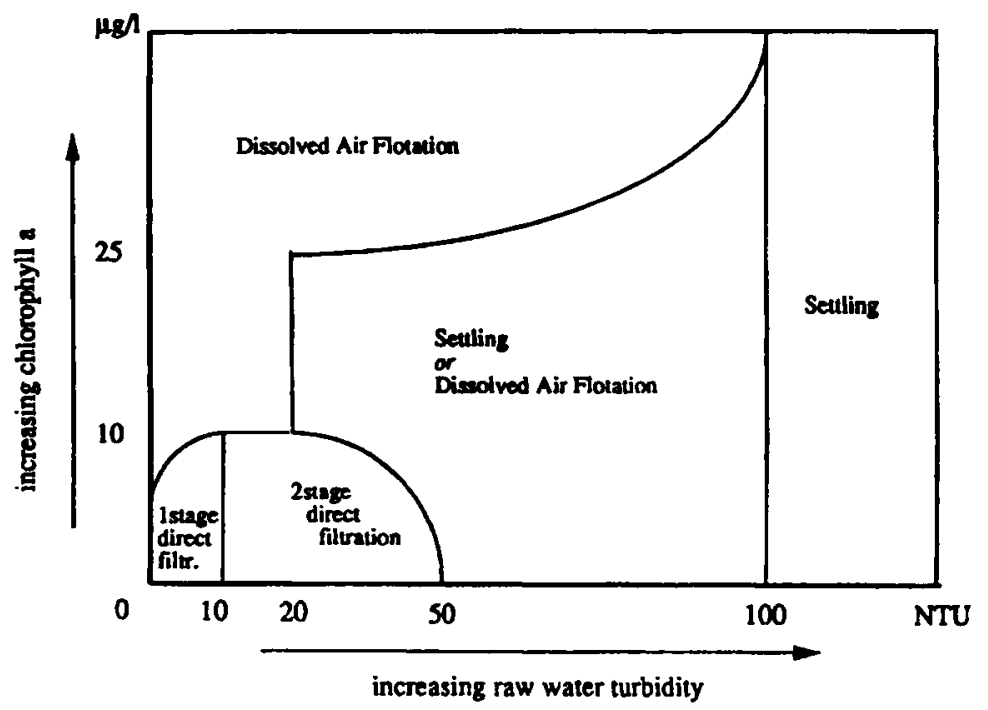

Fig. 1.7 Typical selection diagram for a water treatment process based on turbidity and chlorophyll-a concentration (from Janssens [40]).

Although this diagram can be very useful, it does not consider a range of factors which may be of substantial impact on the choice of process technology. Such factors include algae morphology and physiology (different species exhibit different response to treatment) [41], the source and character of turbidity, temperature, colloidal and particulate matter concentration, and possibly other factors as well. Furthermore, the choice of technology is largely a matter of cost-benefit analysis, suggesting that this diagram can be considered only as indicative.

A typical layout of a DAF treatment plant is presented in Fig. 1.8. It consists of a tank in which two zones are distinguished : (i) the contact zone, and (ii) the separation zone.

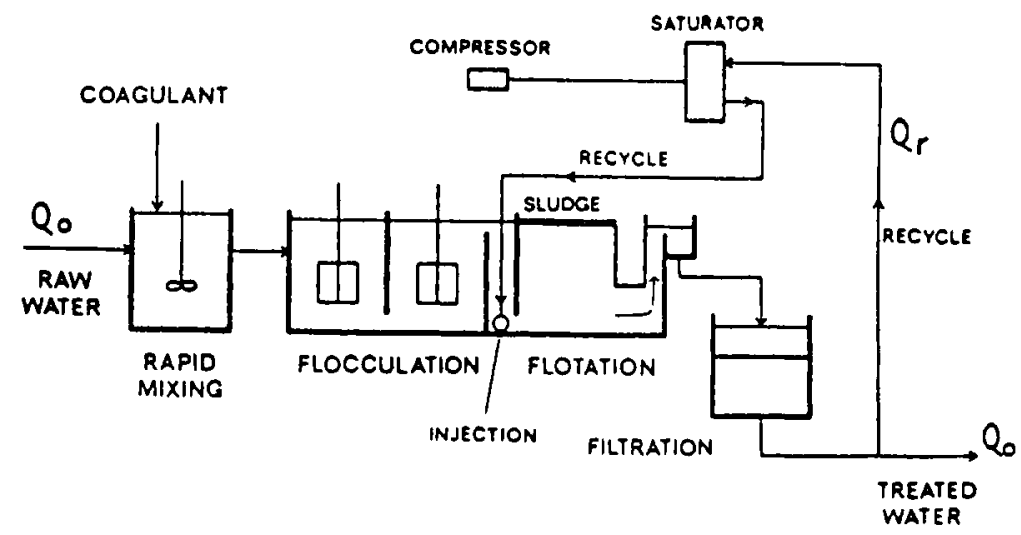

Fig. 1.8 Schematic presentation of a DAF treatment plant [42]. 
In DAF, air is introduced into the contact zone via a pressurised (approximately $500 \mathrm{kPa}$ ) recycled stream of treated water (5-10\% of total flow). The change of pressure from e.g. 500 $\mathrm{kPa}$ to atmospheric results in the production of numerous microscopic (10-100 $\mu \mathrm{m})$ air bubbles which attach to the particles (flocs). The commonly large ratio between air bubble and particle concentration of $10^{2}-10^{3}$, encountered in normal surface water treatment, is suggested responsible for the high DAF efficiency [42]. The particle-bubble agglomerates rise to the surface in the separation zone, where they are easily skimmed off as a light foam.

The following advantages of DAF are proposed [43]:

-small surface needed for unit and equipment;

-low civil engineering cost requirements;

-typical reduction of $10-20 \%$ in chemicals consumption as compared to conventional sedimentation;

-high dry solids content of the sludge (4-6\%), compared to sedimentation (2-4\%);

-lower water losses (1\%, compared to $3 \%$ for sedimentation) due to production of sludge with a higher solids content;

-less affected by flow variations;

-suitable for intermittent use, reaching steady quality after approximately $60 \mathrm{~min}$;

-operates in cold climates with minimum flotation time less than $10 \mathrm{~min}$, and less sensitive to temperature variations than sedimentation;

-high algae removal efficiency.

Disadvantages include higher operational costs and the requirement to have skilled operating personnel. Nevertheless, for treating water with high algal count and relatively low turbidity DAF appears to be the most cost-effective technology. Water with high turbidity, on the other hand, is also treatable to a certain limit and with appropriate process modifications.

\subsubsection{Agglomeration (coagulation/flocculation) of algae}

The single collector collision efficiency DAF kinetic model proposed by Malley and Edzwald [45] recognises two sets of variables that define process efficiency :

-pre-treatment variables ahead of the flotation tank, which influence the particle-bubble attachment efficiency, the particle concentration and the particle-bubble collision efficiency;

-design and operation variables within the flotation tank, which influence the bubble size and concentration.

The agglomeration (coagulation/flocculation) step is a critical part of the DAF; it therefore deserves to receive priority in comprehensive research approach. Such comprehensive optimisation should take into account the down-stream filtration. Neither conventional sedimentation, nor advanced DAF are able to remove on their own the number of algae encountered in eutrophied surface water. Model calculations suggest that the particle destabilization degree is more important than the floc size [42]. $\mathrm{pH}$ and coagulant dose that 
produce floc particles with little or no charge, generally result in favourable flotation conditions. Particles (algae) must be destabilized for good particle attachment to bubbles, as algae stability is caused mainly by : (i) the electrostatic repulsive force due to the negative surface charge (at $\mathrm{pH}$ 2.5-11.5), and (ii) the steric hindrance due to the water layer associated with hydrophilic surface and the adsorbed EOM at the cell surface [42]. Bernhardt and Clasen [45] conclude that algal cells can be considered to behave as inert particles and that the classical coagulation theory therefore is applicable; algae could be destabilized, aggregated and thus brought into filterable form, by adsorption coagulation or sweep coagulation. This can be achieved by charge neutralization by means of adsorption of positively charged organic or inorganic polyelectrolytes, or by metal hydrolysates when sweep coagulation is applicable. Agglomeration conditions that produce particles with little or no charge generally result in efficient DAF [42]. The selection of inorganic or organic coagulants as sole coagulants or coagulant aids, $\mathrm{pH}$, and other coagulation variables therefore need further study.

The kinetic variables ( $\mathrm{G}$ and $\mathrm{t}$ values) for efficient mixing and coagulation, as well as flocculation (i.e. creating particle collision opportunities) similarly need to be optimised. Unlike mixing and coagulation which take place almost instantly after coagulant addition (floc formation starts within $10^{-2} \mathrm{~s}$ up to a few seconds), the floc formation requires lower mixing energy input (low G) during longer time periods (5-20 min), enabling particles to collide. In practice, floc formation and floc break-up occur simultaneously, making application of mechanistic models complicated. However, floc size and strength determine overall efficiency in the floc removal step. While efficient sedimentation requires larger, heavier and easily settleable flocs, the floc size of $10 \mu \mathrm{m}$ to few tens of micrometer has been shown to be optimal for flotation [42, 44]; similar to filtration, flotation efficiency worsens for particle size of $1 \mu \mathrm{m}$ and is one to two orders of magnitude lower for particles $<1 \mu \mathrm{m}$. Floc growth spurs initially by the presence of small but numerous primary particles, and thereafter it is determined by the collision of 'micro-aggregates'. In case of adsorption coagulation, as floc size increases, the number of polyelectrolyte bridges per particle decreases proportionally to floc size and the floc becomes weaker and more susceptible to shear by hydrodynamic forces.

Algal cell aggregates in particular appear to be susceptible to shear and hence turbulence. A shear -free transport of flocculated algae to further treatment is required. A critical location in DAF is the injection of the recirculated water through the injection nozzles or needle valves. Depending on the configuration of the DAF unit, flocs may be locally subjected to high shear. This suggests that longer flocculation times to produce larger flocs are questionable, if flocs break up anyway near the nozzles. Some authors [35] conclude that the flocculation time therefore does not affect flotation performance (based on turbidity measurements); good results can be obtained without flocculation or slow mixing, with flocs formation limited to the rapid mixing period of about 2 minutes. Others [46] suggest minimum flocculation time of 5-6 minutes. On the other hand, flocculation time e.g. at the Scheveningen flotation plant of DZH is in the range of 20-40 min, while in the Lindenbergh flotation plant of EWR it is $25 \mathrm{~min}$.

Optimal agglomeration finally depends very much on the dominant algal species. Cyanobacteria appear in different sizes, shapes and forms, and differ in their EOM composition, which is known to influence the agglomeration process to a great extent. It can be expected that different species and seasonal conditions require different sets of optimal 
agglomeration conditions for subsequent flotation. This calls for further study of the influence of morphological and physiological characteristics of alga species on the agglomeration and down-stream removal efficiency.

Particle (floc) characterisation such as automated particle count or computer image analysis becomes an essential tool in the assessment of the coagulation/flocculation and DAF process assessment.

\subsubsection{Conditioning of algae}

Recent advances in DAF operation pertain to the decrease of the flocculation and flotation time, and other process improvements related to the critical agglomeration (coagulation/flocculation) step. In addition, it was found that oxidants may under certain conditions (depending on raw water quality, coagulant dosage, location of dosing, etc.) improve coagulation and flocculation and hence down-stream floc removal efficiency. The positive experiences, especially with ozone [38, 47, 48] and $\mathrm{KMnO}_{4}[39]$ in direct filtration, warrant further research on these oxidants prior to aggregation and DAF.

Although their use is not yet widespread, the application of oxidants as flocculation aid is becoming a viable option. In this context, the term conditioning seems appropriate to express the effect of oxidants on the algae structure and the resulting flocculation benefits. Namely, in addition to disinfection, secondary benefits arise from their effect on the surface chemistry of colloidal and suspended particles. As a consequence ozone can cause microflocculation (spontaneous flocculation), and hence coagulant dose reduction, improved water quality (measured as turbidity), and reduction in filter bed head-loss [47]. The mechanism of the induced flocculation is not yet fully understood; several mechanisms are proposed by Langlais et al. [49]: (i) reactions with algae, (ii) reduction of particle stability due to loss of adsorbed organic matter from natural particles, (iii) polymerization of natural organic matter (NOM), and (iv) break-up of metal-organic complexes yielding in situ iron production of metal coagulant.

The commonly recommended oxidant in DAF has been ozone, whether as a classical conditioner or for ozoflotation. Ozone reacts with the algal outer cells layer (EOM) and the algal cells themselves; the extent of oxidation depends on the algal species, making its effect seasonally dependent $[38,47]$. Similarly, overdosing can break-up colonies, and damage cell structure. As one consequence, DOC and AOC levels may increase, as well as the toxins concentration [50, 51]. The optimization of the ozone dose for efficient aggregation and flotation, and the understanding of the process kinetics require further study. As an alternative $\mathrm{KMnO}_{4}$ is not commonly applied as a disinfectant and little is known about its optimal use. Its efficiency as a conditioner is related to its oxidative activity and the coagulating effect of the hydrous manganese dioxide floc which is formed when the permanganate is reduced $[39,52]$.

Physical conditioning commonly consists of straining and its efficiency depends on algal size and shape. Microstraining is widely applied with mesh size usually in the range of $35 \mu \mathrm{m}$. Mesh sizes as low as $5 \mu \mathrm{m}$ are commercially available, their application depends largely on 
local raw water plankton and suspended matter concentration and composition. The experience in the five studied Dutch enterprises shows that microstrainers can substantially reduce the algal loads on the subsequent treatment step [19]. However, algae blooms often create problems in the operation of the microstrainers resulting in deteriorating effluent quality. Single cells of Microcystis spp. and Oscillatoria spp., although with distinctly different morphological features, have both been noted to pass through this treatment as in case of the WRK III and PWN treatment plant, causing increased algae counts in the final effluent. The current understanding of the role of this treatment step in the optimisation of the overall treatment scheme can benefit from further pilot studies.

Finally, the use of other physical conditioners such as UV light has not been considered to our knowledge. Its applicability as an efficient disinfectant is yet gaining increasing recognition [53]. UV light is not considered to be an efficient algicide as high dosages $\left(\sim 5000 \mathrm{~J} / \mathrm{m}^{2}\right)$ and long exposure times (several minutes) are probably necessary. Yet, its effect on the viability of algae and hence on aggregation and down-stream flotation, should position it as a potentially interesting research topic.

\subsection{CONCLUSIONS}

The problems related to the periodical high concentrations of algae, are assessed for five Dutch surface water treatment locations. Cyanobacteria, especially $M$. aeruginosa and $O$. agardhii are recognised as the most significant problem causing algae. Examples of efficient reservoir management including deep reservoir operation (WRK III and PWN since recently), coagulation/flocculation and settling within the reservoir (WRK III and DZH), periodical destratification mixing (WRK III), phosphate removal by coagulation/flocculation and settling prior to the reservoir (GWA), can substantially diminish the algae load on subsequent treatment. Water treatment plant managers and operators should carefully consider such positive experiences and investigate their applicability and feasibility in their circumstances. Nevertheless, high algae concentrations, and especially blooms, can still cause numerous treatment problems. This forces water companies to adapt short-term and long-term process modifications, which raises production costs. This raises the issue of further cost-benefit algae treatment optimisation, as well as the viability and applicability of advanced treatment technologies. Increase of the knowledge basis on these issues should improve treatment process operation and raise the confidence in the application of new more efficient technologies. Existing algae related treatment problems and recent research results suggest that there is still a large operational window for increasing the efficiency of existing treatment capacities, based on the cost-benefit principle.

Considering the natural tendency of algae to float, and the positive experiences elsewhere, dissolved air flotation emerges as an attractive treatment technology, as alternative to conventional sedimentation. It features a high rate, high efficiency, low chemicals consumption, and high versatility and adaptability. On the other hand, discrepancies exist between literature and practice, which suggests that optimisation would benefit from DAF further research. The fact that in the nineties many treatment plants in Western Europe will require an increase in production capacity (in our study GWA, DZH and GWG) due to 
increased water consumption, or to upgrade the process efficiency due to more stringent water quality regulations, compound this opinion. DAF is also an attractive option to be considered as pre-treatment in combination with emerging membrane technology in case of high algal loads.

Research in the Netherlands should preferably focus on the process optimization of a comprehensive DAF-based treatment scheme for the removal of cyanobacteria species, notably Microcystis spp. and Oscillatoria spp. An integrated approach is preferred for this purpose, which includes the up-stream agglomeration (coagulation/flocculation) of particles, as well as down-stream filtration. The emphasis is to be placed on the agglomeration phase which is considered critical, whether of particles (algae) in the coagulation/flocculation stage or of particles (algae) and bubbles in the DAF stage. The effects of pre-treatment and conditioning steps on overall process efficiency should be assessed. Positive and negative side effects of the treatment must be assessed, especially with regard to the level of DOC and its AOC fraction in the effluent, because of the possibility of cell disruption by the oxidants. The same applies to the toxin levels in the effluent, which are considered a second priority, but are more difficult to quantify. Finally, the influence of algal morphology and physiology on the process mechanisms need to be investigated.

The evaluation of the process efficiency should be related to the kinetic parameters and rely on more comprehensive particle characterisation. This should include comparison of particle (floc) size frequency and volume distribution for raw water, for water subject to aggregation (coagulation/flocculation), and for treated water. Bubble size characterisation (size distribution) and particle charge related phenomena are also to be considered. This would enable characterisation of process efficiency in a qualitative and quantitative manner, and further clarify important aspects of process kinetics.

\section{REFERENCES}

1. VEWIN Tienjarenplan-hoofdrapport, 1989. Ten year plan - main report (published by the Dutch Water Supply Companies' Association).

2. Watson A. M., 1990. The filtration of algae - Ph.D. thesis, University College, London.

3. Reynolds C.S., 1984. The ecology of freshwater phytoplankton, Cambridge University Press, Cambridge, UK.

4. Hutson R.A., Leadbeater B.S.C. and Sedgwick R.W., 1987. Algal interference with water treatment processes. Progress in Phycological Research, 5, pp. 266-297, (edited by Round/Chapman), Biopress Ltd.

5. Sandgren C.D. (editor), 1988. Growth and reproductive strategies of freshwater phytoplankton, Cambridge University Press, Cambridge, UK, pp. 261-316.

6. National Rivers Authority (NRA) report, 1990. Toxic blue green algae, Water Quality Series, UK.

7. Carr N.G. and Whitton B.A. (editors), 1982. The biology of cyanobacteria-Botanical Monographs, Vol. 19, Blackwell Scientific Publications, UK.

8. Lawton L. and Codd G.A., August 1991. Cyanobacterial (blue-green algal) toxins and their significance in UK and European waters - J. IWEM., pp. 460-465. 
9. Hallegraeff G.M., 1991. Massive bloom of toxic blue-green algae in Australian rivers. pp.7.

10. Di Bernardo L., 1995. Algas e suas influências na qualidade das águas e nas tecnologias de tratamento (Algae and their influence on water quality and treatment technology). Ediçâo Patrocinada pela ABES Associaçâo Brassileira de Enhenharia Sanitária e Ambiental, Brasil.

11. Sivonen K., Niemela S.I., Niemi R.M., Lepisto L., Luoma T.H. and Rasanen L.A., 1990. Toxic cyanobacteria (blue-green algae) in Finnish fresh and coastal waters, Hydrobiologia 190, pp. 267-275.

12. Hoekstra A.C., Bol J. and Seinen W., 1991. Blauwwieren en hun toxinen in voor drinkwaterproduktie gebruikt oppervlaktewater (Blue-greens and their toxins in surface water used for drinking water production), $\mathrm{H}_{2} \mathrm{O}, 14,91$, pp. 387-393.

13. Speedy R.R., Fisher N.B. and McDonald D.B., June 1969. Algal removal in unit processes - J. $A W W A, 61$, pp. 289-292.

14. Kay P., Sykora J.L. and Burgess R.A., March 1980. Algal concentration as a quality parameter of finished drinking waters in and around Pittsburgh, $\mathrm{Pa} .-J . A W W A$., 72, pp. 170-176.

15. Falconer I.R, Runnegar M.T.C., Buckley T., Huyn V.L., and Bradshaw P., 1989. Using activated carbon to remove toxicity from drinking water containing cyanobacterial blooms -J. $A W W A, 81$, pp. 102-105.

16. Codd G.A. and Bell S.G., 1985. Eutrophication and toxic cyanobacteria in freshwaters Wat. Poll. Control., pp. 225-231.

17. Sugiura N., Inamori Y. and Sudo R., 1990. Degradation of blue-green alga, Microcystis aeruginosa by flagellata, Monas guttula - Environmental Technology, 11, pp. 739-746.

18. Vlaški A. and A.N.van Breemen, 1992. A preliminary investigation of the membrane filtration index and characterization of particles, of water produced at WRK III treatment plant, (internal research report), TU-Delft, the Netherlands.

19. Vlaški, A., van Breemen, A.N., Alaerts, G.J., 1994. Algae and Water Treatment in the Netherlands, Problem Analysis and Treatment Strategies in Five Water Companies. International Institute for Infrastructure, Hydraulic and Environmental Engineering -Delft (IHE), Working Paper EE - 1, Delft, the Netherlands.

20. Vollenweider, R.A. Scientific fundamentals of the eutrophication of lakes and flowing waters, with particular reference to nitrogen and phosphorus as factors in eutrophication. OECD, report DAS/CSI/68.27, Paris, 1971.

21. Sakamoto M., 1966. Primary production by phytoplankton community in some Japanese lakes and its dependence on lake depth. Arch. Hydrobiol., 62, pp. 1-28.

22. Dillon P.J. and Rigler F.H., 1974. The phosphorus-chlorophyll relationship in lakes. Limn. and oceanography, 19, 5, pp. 767-773.

23. Tillman D., Castling R, Sterner R., Killam S.S. and Johnson FA, 1986. Green, bluegreen and diatom algae: Taxonomic differences in competitive ability for phosphorus, silicon and nitrogen. Arch. Hydrobiol., 106, 4, pp. 473-485.

24. Harris G.P., 1986. Phytoplankton ecology : structure, function and fluctuations. Chapman and Hall Ltd., London, UK.

25. Schreurs H., 1989. Cyanobacterial dominance, relations to eutrophication and lake morphology. Ph.D. thesis University of Utrecht, the Netherlands.

26. Mc Dougal B.K. and Ho G.E., 1991. A study of the eutrophication of North Lake, Western Australia, Wat. Sci. Techn., 23, pp. 163-173. 
27. Seitzinger S.P., 1991. The effect of $\mathrm{pH}$ on the release of phosphorus from Potomac estuary sediments: Implications for blue-green algal blooms, Estuarine Coastal and Shelf Science, 33, pp. 409-418.

28. Dickens C.W.S. and Graham P.M., 1995. The rupture of algae during abstraction from a reservoir and the effects on water quality. $J$. Water $S R T-A q u a, 44,1$, pp.29-37.

29. Bernhardt H. and Clasen J., 1991. Flocculation of micro-organisms. J.Water SRT-Aqua, 40, 2, pp. 76-87.

30 Streble H. and Krauter D., 1973. Das leben im Wassertropfen, Kosmos Gesellschaft der Naturfreunde Franckh'sche Verlagshandlung, Stuttgart, Germany.

31 Oskam G. and van Genderen J., 1995. Eutrophication and development of algae in surface water - a threat for the future ? Special subject 8, IWSA - Congress, Durban, South Africa.

32 Van der Kooij D., 1990. Assimilable organic carbon (AOC) in drinking water. In : Drinking Water Microbiology, editor G.A. McFeters, Springer-Verlag, pp. 57-87.

33. Gehr R., Swartz C. and Offringa G., 1993. Removal of trihalomethane precursors from eutrophic water by dissolved air flotation. Wat. Res., 27, 1, pp. 41-49.

34. Malley J.P., 1990. Removal of organic halide precursors by dissolved air flotation vs. conventional water treatment. Environmental Technology, 11, pp.1161- 1168.

35. Malley J.P. and Edzwald J.K., 1991. Laboratory comparison of DAF with conventional treatment. J. $A W W A, 83, \mathrm{pp} .56-61$.

36. Roux le J.D., 1988. The treatment of odorous algae-laden water by dissolved air flotation and powdered activated carbon, National Institute for Water Research, CSIR, South Africa, 1988, pp. 72-79.

37. Amold, R.S. and Harvey P., 1994. Recent applications of DAF pilot studies and full scale design, IAWQ-IWSA-AWWA Joint Specialised Conference on Flotation Processes in Water and Sludge Treatment, Orlando, USA.

38. Petruševski B., van Breemen A. N., van Aelst A.C. and Alaerts G.J., 1994. Preozonation : key for efficient particle and algae removal in direct filtration, Proceedings IOA Regional Conference, Zurich, Switzerland.

39. Petruševski B., van Breemen A.N. and Alaerts G.J., 1995. Effect of permanganate pretreatment and coagulation with dual coagulants on algae removal in direct filtration, IAWQ/IWSA Workshop on Removal of Microorganisms From Water and Wastewater, Amsterdam, the Netherlands.

40. Janssens J.G., 1992. Design concepts and process selection for particle removal in surface water treatment. Lecture notes - Actvanced design concepts for integral drinking water treatment IHE-Delft, the Netherlands.

41. Petruševski B., Vlaški A., van Breemen A.N. and Alaerts G.J., 1993. Influence of algae species and cultivation conditions on algal removal in direct filtration. Wat. Sci. Tech., 27, 11, pp.221-220.

42. Edzwald J.K. and Wingler B.J., 1990. Chemical and physical aspects of dissolved-air flotation for the removal of algae. J.Water SRT-Aqua, 39: 24-35.

43. Zabel T., 1985. The advantages of dissolved-air flotation for water treatment. J. $A W W A$, 77, pp. $42-46$.

44. Malley J.P. and Edzwald J.K., 1991. Concepts for dissolved-air flotation treatment of drinking waters. J. Water SRT-Aqua, 40, 1, pp. 7-17. 
45. Bemhardt H. and Clasen J., 1992. Studies on removal of planktonic algae by flocculation and filtration Water Maloysia '92, 8th ASPAC - IWSA Regional Water Supply Conference \& Exhibition, Technical papers, Volume 2.

46. Janssens J.G., 1990. The application of dissolved air flotation in drinking water production, in particular for removing algae. DVGW Wasserfachlichen Aussprachetagung Essen - Federal Republic of Germany.

47. Edzwald J.K. and Paralkar A., 1992. Algae, coagulation, and ozonation. Chemical Water and wastewater treatment II. Klute R. and Hahn H.(Eds.), Springer-Verlag, Germany, pp. 263-279.

48. Bourbigot M-M, Martin N., Faivre M., Le Corre K. and Quennell S., 1991. Efficiency of an ozoflotation-filtration process for the treatment of the River Thames at Walton Works. J.Water SRT-Aqua, 40, 2, pp 88-96.

49. Langlais B., Reckhow D.A. and Brink D.R. (eds.), 1991. Ozone in water treatment application and engineering. AWWARF Cooperative report, Lewis Publ., Chelsea, Mich.,USA, pp. 190-213.

50. Falconer I.R., Runnegar M.T.C., Buckley T., Huyn V.L., and Bradshaw P., 1989. Using activated carbon to remove toxicity from drinking water containing cyanobacterial blooms. J. $A W W A, 81$, pp. 102-105.

51. Sukenik A., Teltch B., Wachs A.W., Shelef G., Nir I. and Levanon D., 1987. Effect of oxidants on microalgal flocculation - Wat. Res., 21, 5, pp. 533-539.

52. Cleasby J.L., Baumann E.R. and Black C.D., 1964. Effectiveness of potassium permanganate for disinfection - J. $A W W A, 56, \mathrm{pp} .466-474$.

53. Kruithof J.C. and Leer van den R.C., 1992. Practical experiences with UV-disinfection in The Netherlands. J. Water SRT-Aqua, 41, pp. 88-94. 
both in the smaller $(<50 \mu \mathrm{m})$ and larger $(>50 \mu \mathrm{m})$ particle size ranges. A low flocculation $G$ value of $10 \mathrm{~s}^{-1}$ resulted in similar and better algae removal efficiency by DAF than the value of $\mathrm{G}=70 \mathrm{~s}^{-1}$, producing a floc size distribution with larger and lighter flocs, favouring efficient DAF. The interaction between the flocculation $G$ and $t$ values was found as the only significant factor affecting the DAF process efficiency, each of them separately having no statistically significant effects on removal efficiency. Thus, apart from the coagulation related charge effects, the particle (floc) size and density which are determined by the flocculation process, play a highly important role in determining the down-stream process efficiency. Under optimal process conditions for DAF and sedimentation no statistically significant efficiency difference was observed for the removal of particles (algae), while the achieved turbidity removal was significantly better by sedimentation than by DAF.

Application of relatively low doses of cationic polyelectrolyte (Superfloc C-573) as coagulant aid ( 0.5 for DAF and $1.0 \mathrm{mg}$ Superfloc C-573/L for sedimentation) in combination with previously optimised coagulant doses and flocculation conditions, increased process efficiency of both processes (without down-stream filtration) up to $99 \%$. Together with an improved removal efficiency achieved by coagulation at low $\mathrm{pH}(\mathrm{pH} 6 \mathrm{vs}$. $\mathrm{pH} 8)$, this suggests adsorption coagulation and charge neutralisation are the main coagulation mechanisms that support the dosage dependant sweep coagulation and improve the overall particle (algae) removal.

Results from bench scale experiments with model water and laboratory cultured $\boldsymbol{M}$. aeruginosa showed that sedimentation or DAF alone is insufficient to cope with moderate to high initial concentrations of this species. Maximum particle (algae) removal efficiency achieved under optimal process conditions was $71 \%$ for DAF ( $3 \mathrm{mg} \mathrm{Fe}(\mathrm{III}) / \mathrm{L}, \mathrm{G}=10$ or $70 \mathrm{~s}^{-1}, \mathrm{t}=10 \mathrm{~min}$ ), and $87 \%$ for sedimentation ( $10 \mathrm{mg} F(\mathrm{III}) / \mathrm{L}, \mathrm{G}=30 \mathrm{~s}^{-1}, \mathrm{t}=30 \mathrm{~min}$ ). An integrated approach including the up-stream agglomeration (coagulation/flocculation) step, as well as the downstream filtration step is essential. Adding a non-optimised filtration step in the experimental set-up increased removal efficiency in both cases, for DAF up to $90 \%$ and for sedimentation up to $95 \%$. The filtration efficiency in this case (small scale filters connected to the jar test apparatus) was generally influenced by the flocculation $G$ value and the resultant floc size/density ratio. It is also speculated that given the relatively low model water TOC of $\approx 2.5$ $\mathrm{mg} / \mathrm{L}$, the residual coagulant (after DAF or sedimentation) is utilised in the filter in a "direct filtration" mode. Thus, the relatively low residual coagulant concentrations (from the point of view of direct filtration) result in relatively low filtration efficiencies. The filtration efficiency itself increased with the residual coagulant increase. Additionally, this situation may be negatively influenced by the (small) scale of the filters - filter wall effects and the non-ripened state of the filter, a situation which will be improved if a fully optimised filtration step is applied.

\section{REFERENCES}

1. Vlaški A., van Breemen A.N. and Alaerts G.J., 1994. Algae and water treatment in the Netherlands, problem analysis and treatment strategies in five water companies. IHE Working Paper EE-1, IHE, Delft, the Netherlands. 
2. Petruševski B., van Breemen, A. N. and Alaerts, G.J., 1994. Optimisation of coagulation conditions for in-line direct filtration. Workshop on Optimal Dosing of Coagulants and Flocculants, Mülheim an der Ruhr, Germany.

3. Edzwald J.K., 1993. Coagulation in drinking water treatment : particles, organics and coagulants. Wat. Sci.Tech., 27, 11.

4. Janssens J.G., 1992. Improved flocculation and dissolved air flotation for algae removal. Emerging Technologies $V$ Conference, Vienna, Austria.

5. Janssens J.G., 1990. The application of dissolved air flotation in drinking water production, in particular for removing algae. DVGW Wasserfachlichen Aussprachetagung Essen, Germany.

6. AWWA Coagulation Committee, 1989. Committee report: coagulation as an integrated water treatment process - committee report, J. AWWA, 81, pp. 72-78.

7. Ives K.J., 1956. Electrokinetic phenomena of planktonic algae. Proc. Soc. Water Trtn. And Exam., 5, pp.41-58.

8. Edzwald J.K., 1993. Algae, bubbles, coagulants and dissolved air flotation - Wat. Sci. Tech., 27, 10, pp. 67-81.

9. Vlaški A., van Breemen A.N. and Alaerts G.J., 1997.Evaluation and verification of the existing dissolved air flotation (DAF) kinetic model (article in preparation), IHEDelft, the Netherlands.

10. Edzwald J.K., 1994. Principles and application of dissolved air flotation - Joint IAWQIWSA Specialised Conference on Flotation Processes in Water and Sludge Treatment, Orlando, USA.

11. Malley J.P., 1994. The use of selective and direct DAF for removal of particulate contaminants in drinking water treatment. IAWQ-IWSA Joint Specialised Conference on Flotation Processes in Water and Sludge Treatment, Orlando, USA.

12. Malley J.P. and Edzwald J.K., 1991. Concepts for dissolved-air flotation treatment of drinking waters - J. Water SRT-Aqua, 40, 1, pp. 7-17.

13. Puffelen van J., 1993. Flotation - State of the art - Cursus moderne drinkwaterzuiveringstechnieken (Course Modern Water Treatment Technologies), Technical University-Delft, Delft, the Netherlands.

14. Boller M.A. and Kavanaugh M.C., 1995. Particle characteristics and headloss increase in granular media filtration. Wat.Res., 29, 4, pp.1139-1149.

15. Bernhardt H. and Clasen J., 1992. Studies on removal of planktonic algae by flocculation and filtration - Technical papers, Volume 2, Water Malaysia '92, 8th ASPAC - IWSA Regional Water Supply Conference, Kuala Lumpur, Malaysia.

16. Bhargava D.S. and Rajagopal K., 1992. An integrated expression for settling velocity of particles in water - Wat. Res., 26, 7, pp. 1005-1008.

17. Patry G.G. and Takacs I., 1992. Settling of flocculent suspensions in secondary clarifiers - Wat. Res., 26, 4, pp. 473-479.

18. Malley J.P. and Edzwald J.K., 1991. Laboratory comparison of DAF with conventional treatment - J. AWWA, 83, pp. 56-61.

19. Edzwald J.K. and Wingler B.J., 1990. Chemical and physical aspects of dissolved-air flotation for the removal of algae - J. Water SRT-Aqua, 39, pp. 24-35.

20. Zabel T., 1985. The advantages of dissolved-air flotation for water treatment $-J$. $A W W A, 77$, pp. 42-46.

21. Petruševski B., Vlaski A., van Breemen A. N. and Alaerts G.J. 1993. Influence of 
algal species and cultivation conditions on algal removal in direct filtration - Wat. Sci. Tech., 27, 11, pp. 211-220.

22. Tompkins J., De Ville M.M., Day J.G. and Turner M.F. (eds.), 1995. Culture collection of algae and protozoa, Catalogue of strains - Titus Wilson \& Son Ltd, Kendal, United Kingdom .

23. Vlaški A., 1991. Aggregation of algae and direct filtration - IHE/TU-Delft, M.Sc. thesis, Delft, the Netherlands.

24. De Rijk S.E., van der Graaf J.H.J.M. and den Blanken J.G., 1994. Bubble size in flotation thickening - Wat. Res., 28, 2, pp. 465-473.

25. Alaerts G.J. and Van Haute A., 1982. Stability of colloid types and optimal dosing in water flocculation - Physicochemical Methods for Water and Wastewater Treatment, Pawlowski L. (ed.), Elsevier Publ., Amsterdam, the Netherlands, pp. 13-29.

26. Bernhardt H. and Clasen J., 1991. Flocculation of micro-organisms - J.Water SRTAqua, 40, 2, pp. 76-87.

27. Schers G.J. and van Dijk J.C., 1992. Flotatie, de theorie en de praktijk (Flotation, the theory and practice), $\mathrm{H}_{2} \mathrm{O}, 11$, pp. 282-290.

28. Mackie R.I. and Bai R., 1993. The role of particle size distribution in the performance and modelling of filtration - Wat. Sci. Tech., 27, 10, pp. 19-34.

APPENDIX 3.1 Composition of the algae cultivating medium (Jaworski) used for semicontinuous culturing of $M$. aeruginosa).

\begin{tabular}{llll} 
ELEMENTS : & CONCENTRATION $(\mu \mathrm{M}):$ & TRACE ELEMENTS : & CONCENTRATION $(\mu M):$ \\
\hline $\mathrm{Ca}_{\mathrm{N}}$ & 84.67 & $\mathrm{~B}$ & 40.0 \\
$\mathrm{~N}$ & 1038.00 & $\mathrm{Mn}$ & 7.00 \\
$\mathrm{~K}$ & 91.10 & $\mathrm{Fe}$ & 5.60 \\
$\mathrm{P}$ & 191.70 & $\mathrm{Mo}$ & 0.81 \\
$\mathrm{Mg}$ & 203.00 & & \\
$\mathrm{~S}$ & 203.00 & & \\
$\mathrm{C}$ & 200.00 & & \\
$\mathrm{Na}$ & 1213.00 & & \\
\hline
\end{tabular}

\begin{tabular}{llll} 
VITAMINS : & CONCENTRATION $(\mathrm{mg} / \mathrm{L}):$ & COMPLEXING AGENTS: & CONCENTRATION (uM): \\
\hline B-12 & 0.04 & EDTA Fe Na & 5.60 \\
B-2 & 0.04 & EDTA Na & 6.04 \\
Biotin & 0.04 & & \\
\hline
\end{tabular}

CULTURING PROCEDURE : The nutrients were added into $1 \mathrm{~L}$ of demineralised water at pH 7 , followed by autoclave for a period of $20 \mathrm{~min}$ at $120^{\circ} \mathrm{C}$. The vitamins solution which had been previously sterilised by filtration at $\mathrm{pH} 7$, was added to the medium afterwards. The incubation of algae $(80 \mathrm{~mL}$ of Microcystis aeruginosa suspension at the end of the logarithmic growth phase) was done in $5 \mathrm{~L}$ glass vessels (Duran 50, Schott Mainz, Jena, Germany) at $20^{\circ} \mathrm{C}$. The algae suspension was aerated with compressed air passed through a sterile $0.2 \mu \mathrm{m}$ filter, while continuous mixing was applied at the bottom of the vessel with a magnetic stirrer. The light cycle was continuous at light intensity of $\pm 1,000$ lux. For this purpose a vertically placed T.L. lamp Osram-Cool White L18 W20 was used, placed at a distance of $0.2 \mathrm{~m}$ from the walls of the vessel. The stationary algae growth phase was reached after an incubation period of 14-17 days, after which $2 \mathrm{~L}$ of the algae suspension were sampled in sterile conditions and used in experiments. The abstracted $2 \mathrm{~L}$ of algae suspension were substituted with fresh medium and incubated under the same conditions for 7-10 days, after which algae were sampled for experiments again. This completed the culturing cycle, after which a new culture was started-up. 
coagulant alone. The $\mathrm{KMnO}_{4}$ conditioning option proved significantly less efficient than the ozone conditioning, especially in terms of particle removal. The relatively high standard deviation of the efficiency results, as well as the occasional change of the permanganate demand, suggested that the organic matter concentration and composition, play an important role in defining the permanganate demand, its chemical effect and the resulting DAF efficiency. The optimal flocculation $\mathrm{Gt}$ range was related to the flocculation and removal of the colloidal $\mathrm{MnO}_{2}$ and was 60,000 (typically $\mathrm{G}=70 \mathrm{~s}^{-1}, \mathrm{t}=15 \mathrm{~min}$ ).

The Mn and coagulant concentrations in the DAF effluent at the optimal permanganate dose were higher than their MAC values. This suggested that cationic polyelectrolytes could reduce the electrostatic repulsion between the oppositely charged $\mathrm{Mn}$ and Fe colloids. The DAF particle and turbidity removal efficiency in the case of cationic polyelectrolyte Superfloc C-573 coagulant aid application resulted in significantly better efficiency than was achieved in the case of iron coagulant only, or in the case of the combination of $\mathrm{KMnO}_{4}$ conditioning and iron coagulant. A particle and turbidity removal efficiency of $95 \%$ and $86 \%$ respectively, were achieved with 0.5 mg Superfloc C-573 as coagulant aid, applied in combination with permanganate and $\mathrm{Fe}$ (III) coagulant. A 5-25\% improvement of turbidity removal efficiency was also noted in comparison with the iron coagulant and cationic polyelectrolyte combination. The observed improvement was achieved via improved removal of both the Fe and $\mathrm{Mn}$ residuals. The option of lowering the residual $\mathrm{Mn}$ by the reducing agent $\mathrm{Na}_{2} \mathrm{SO}_{3}$ proved potentially viable. In any case, other studies proved that residual $\mathrm{MnO}_{2}$ can be efficiently removed in a final filtration step.

Appendix 4.2 synthesizes the DAF particle and turbidity removal efficiency achieved under different treatment combinations.

\section{REFERENCES}

1. Bernhardt H. and Clasen J., 1992. Studies on removal of planktonic algae by flocculation and filtration. Technical papers, 2. Water Malaysia '92, 8th ASPAC-IWSA Regional Water Supply Conference, Kuala Lumpur, Malaysia.

2. Zabel T., 1992. The advantages of dissolved air flotation for water treatment. JAWWA, 77, pp. 42-46.

3. Vlaški A., van Breemen A.N. and Alaerts G.J., 1995. Optimisation of Coagulation Conditions for the Removal of Cyanobacteria by Dissolved Air Flotation or Sedimentation. J.Water SRT-Aqua, 45, 5, pp. 253-261.

4. Berger M. and Carnahan R.P, 1991. Fouling prediction in reverse osmosis processes. Desalination, 83, pp.3-33.

5. Edzwald J.K., 1993. Coagulation in drinking water treatment : particles, organics and coagulants. Wat. Sci. Tech., 27 (11).

6. Edwards M. and Benjamin M.M., 1992.Effect of preozonation on coagulant-NOM reactions. $J A W W A, \mathbf{8 4}$, pp. 63-72.

7. Randtke S.J., 1988. Organic contaminant removal by coagulation and related process combinations. JAWWA, 80, pp.40.

8. Davis J.A., 1982. Adsorption of natural dissolved organic matter at the oxide/water interface. Geochim. Et cosmochim. Acta, 46, pp. 2381. 
9. Stumm W and Morgan J., 1962. Chemical aspects of coagulation. JAWWA, 54, pp. 971992.

10. Bratby J., 1980. Coagulation and flocculation. Upland Press Ltd., England.

11. Bernhardt H. and Clasen J., 1991. Flocculation of micro-organisms - J.Water SRT-Aqua, 40, 2, pp. 76-87.

12. Ives K.J., 1959. The significance of surface electric charge on algae in water purification. J. Biochem. And Microb. Techn. Eng., 1, 1, pp. 37-47.

13. Vlaški A., van Breemen A.N. and Alaerts G.J., 1996. The role of particle size and density determining dissolved air flotation and sedimentation efficiency. 4th IAWQ-IWSA International Conference on The Role of Particle Characteristics in Separation Processes, Jerusalem, Israel.

14. Bemhardt H., Schell H. And Lusse B., 1986. Criteria for the control of flocculation and filtration processes in water treatment of reservoir water. Water Supply, 4, pp. 99-116.

15. Stumm W. and Sigg L., 1972. Kolloidchemisch grundlagen der phosphorelimination in fallung, flockung und filtration. $Z$ Wasser-Abwasser-Forsch, 12, pp. 73-83.

16. Packham R.F., 1965. Some studies of the coagulation of dispersed clays with hydrolysed salts. J. Coll. Sci, , 20, pp. 81-92.

17. Gregory J., 1983. Chemistry and technology of water soluble polymers. Ed. Finch C.A., Plenum Press, pp. 307-320.

18. Kawamura S., 1991. Effectiveness of natural polyelectrolytes in water treatment. $J A W W A$, 83, pp. 73-81.

19. Habibian M.T. and O'Melia C.R., 1975. Particles, polymers and performance in filtration. J. Envir. Eng. Div.- ASCE, 101, pp. 567-583.

20. Tenney M.W., Eichelberger W.F. Schuessler R.G. and Pavoni J.L., 1969. Algal flocculation with synthetic polymeric flocculants. Applied Microbiology, 18, pp. 965-971.

21. Tilton R.C., Murphy J. And Dixon J.K., 1972. The flocculation of algae with synthetic polymeric flocculants. Wat. Res., 6, pp. 155-164.

22. Petruševski B., van Breemen A.N. and Alaerts G.J., 1995. Effect of permanganate pretreatment and coagulation with dual coagulants on particle and algae removal in direct filtration. Proc. IAWQ-IWSA Workshop on Removal of Microorganisms from Water and Wastewater, Amsterdam, the Netherlands.

23. Malley J.P., 1994. The use of selective and direct DAF for removal of particulate contaminants in drinking water treatment. Joint IAWQ-IWSA Specialised Conference on Flotation Processes in Water and Sludge Treatment, Orlando, Fl., USA.

24. Janssens J.G., van Hoof F. and Dirickx, 1986. Study on preozonation and prechlorination applied in the treatment of surface waters from impounding reservoirs. Proc. AWWA Annual Conference, Part 2, Kansas City, Mo., USA.

25. Jodlowski A., 1990. Preoxidation effect on algae coagulation related to direct filtration water treatment. Internal Report, Delft University of Technology, Delft.

26. Langlais B., Reckhow D.A. and Brink D.R., editors, 1991. Ozone in Water Treatment Applications and Engineering. Lewis Publishers, Chelsea, Mi, USA.

27. Sukenik A., Teltch B., Wachs A.W., Shelef G., Nir I. And Levanon D., 1987. Effect of oxidation on microalgal flocculation. Wat. Res., 21, 5, pp. 533-539.

28. Singer P.C. and Chang S.D., 1988. Impact of ozone on the removal of particles, TOC and THM precursors. AWWA Research Foundation Report, AWWA, Denver, Co., USA.

29. Jekel M.R., 1983. The benefits of ozone treatment prior to flocculation processes. Ozone Sci. And Eng., 5, pp. 21-35. 
30. Vlaški A., van Breemen A.N. and Alaerts G.J., 1997. Algae laden water treatment by dissolved air flotation (DAF). Proc. CIWEM International Conference Dissolved Air Flotation - an Art or a Science?, London, United Kingdom.

31. Krasner W.S., Glaze W.H., Wienberg H.S., Daniel P.A. and Najm I.N., 1993. Formation and control of bromate during ozonation of waters containing bromide. JAWWA, 85, pp.73-81.

32. Kruithof J.C., Meijers R.T., and Schippers J.C., 1993. Formation, restriction of formation and removal of bromate. Wat. Supply, 11, 3/4, pp. 331-342.

33. Kruithof J.C. and Meijers R.T., 1993. Presence and formation of bromate in Dutch drinking water treatment. Proc. AIDE/IWSA International Workshop : Bromate and Water Treatment, Paris, France.

34. Schalekamp M., 1986. Pre- and intermediate oxidation with ozone, chlorine and chlorine dioxide. Wat. Supply, 4, pp. 499-522.

35. Reckhow D.A., Singer P.C. and Trussell R.R., 1986. Ozone as a coagulant aid. $A W W A$ National Conference, Sunday Seminar on Ozonation : Recent Advances and Research Needs, USA.

36. Petruševski B., 1996. Algae and particle removal in direct filtration of Biesbosch Water, Influence of algal characteristics, oxidation, and other pre-treatment conditions. Ph.D. thesis, published by A.A. Balkema, Rotterdam, the Netherlands.

37. Von Gunten U. and Hoigné J., 1993. Bromate formation during ozonation of bromide containing waters. Proc. IOA World Congress, San Francisco, USA.

38. Siddiqui M.S. and Amy G.L., 1993. Factors affecting DBP formation during ozonebromide reactions. $J A W W A, 85$, pp. 63-72.

39. Orlandini E, Kruithof J.C., van der Hoek J.P., Siebel M.A. and Schippers J.C., 1997. Ozonation in Biological activated carbon filtration : it's effect on bromate, Assimilable Organic Carbon and the $\mathrm{Ct}$ value. J. Water SRT-Aqua, 46, 1, pp. 20-30.

40 Kooij van der D., 1992. Assimilable organic carbon as an indicator of bacterial regrowth. J. $A W W A, 84,2$.

41. Orlandini E., Siebel M.A., Graveland A. and Schippers J.C., 1994. Pesticide removal by combined ozonation and GAC filtration, Water Supply, 14, pp. 99-108.

42. Ma J. and Li G., 1993. Laboratory and full scale plant studies of permanganate oxidation as an aid in coagulation. Wat. Sci. Tech., 27, 11, pp. 47-54.

43. Edzwald J.K. and Paralkar A., 1992. Algae, coagulation, and ozonation - Chemical Water and wastewater treatment $I I$, Klute R. and Hahn H.(Eds.), Springer-Verlag, Germany, pp. 263-279.

44. Ginocchio J.C., 1981. Effect of ozone on the elimination of various algae by filtration. Ozonation Manual for Water and Wastewater Treatment, edited by Masschelein W.J., J.Wiley.

45. Singer P.C., 1990. Assessing ozonation research needs in water treatment. J. $A W W A, \mathbf{8 2}$, pp.78-88.

46. Dowbiggin B. And Singer P.C., 1989. Effects of natural organic matter and calcium on ozone-induced particle destabilisation. $J A W W A, 81$, pp. 77-85.

47. Chang S.D. and Singer P., 1991. The impact of ozonation on particle stability and removal of TOC and THM precursors. JAWWA, 84, pp. 63-72.

48. Ficek J.K., 1978. Potassium permanganate for iron and manganese removal and taste and odour control. Water treatment plant design, edited by Sanks R.L., Ann Arbor Publishers Inc., Mi., USA. 
49. Middlemans E.R. and Ficek J.K., 1986. Controlling the potassium permanganate feed for taste and odour treatment. AWWA Annual Conference, Denver. Co., USA.

50. Emanuel A.G., 1965. The chemistry and application of potassium permanganate in water treatment. South West America Water Works Association Meeting, Carus Chemicals Co., La Salle, Ill., USA.

51. Willey B.F. and Jennings H., 1963. Iron and manganese removal with potassium permanganate. $J A W W A, 65$, pp. 729-735.

52. Fitzgerald G.P., 1964. Evaluation of potassium permanganate as an algicide for water cooling towers. I\&EC Product Research and Development, 3, 2, pp. 82-85.

53. Kemp H.T., Fuller P.G. and Davidson R.S., 1966. Potassium permanganate as an algicide. $J A W W A, 59$, pp. 255-263.

54. Bernhardt H., and Lusse B., 1989. Elimination of zooplankton by flocculation and filtration. J. Water SRT-Aqua, 38, 1, pp. 23-31.

55. Ficek J.K. and Boll J.E., 1980. Potassium permanganate : an alternative to prechlorination. Aqua, 7, pp. 153-156.

56. Colthurst J.M. and Singer P.C., 1982. Removing trihalomethane precursors by permanganate adsorption. $J A W W A, 74$, pp. 78-83.

57. Ma J., and Graham N., 1996. Controlling the formation of chloroform by permanganate preoxidation-destruction of precursors. J. Water SRT-Aqua, 45, 6, pp. 308-315.

58. Willey B.F., Jennings H. And Muroski F., 1964. Removal of hydrogen sulphide with potassium permanganate. $J A W W A, 50, \mathrm{pp} .475-479$.

59. Ficek J.K. Potassium permanganate "The unique water treatment oxidant'. Carus Chemical Company, La Salle, Ill., USA.

60. Posselt H.S., Anderson F.J. and Weber W.J., 1968. Cationic sorption on colloidal hydrous manganese dioxide. Env. Sci. And Techn., 2, 12, pp. 1087-1093.

61. Weltch W.A., 1962. Potassium permanganate in water treatment. Conf. Paper, Chesapeake Section Meeting, Wilmington, Ill., USA.

62. Nederlands Normalisatie Instituut, 1982. NEN: 6460: Water - Determination of iron content by atomic absorption spectrometry (flame technique).

63. Nederlands Normalisatie Instituut, 1982. NEN: 6466: Water - Determination of manganese content by atomic absorption spectrometry (graphite furnace technique).

64. APHA, AWWA and WPCF, 1985. Standard methods for examination of water and wastewater, Am. Publ. Health Assoc., Washington D.C., USA.

65. Janssens J.G., 1990. The application of dissolved air flotation in drinking water production, in particular for removal of algae. DVGW Wasserfachlichen Aussprachetagung, Essen, Germany.

66. Rees A.J., Rodman D.J. and Zabel T.F., 1979. Water clarification by flotation - 5, Technical report TR114, Water Research Centre, UK.

67. Wobma P, Bellamy B., Pernitsky D., Kjartanson K., Adkins M. And Sears K., 1997. Effects of dissolved air flotation on water quality and filter loading rates. Conference proceedings, CIWEM (Chartered Institution of Water Institution and Environmental Management) International Conference on Dissolved Air Flotation in Water Treatment an art or a science?, London, UK, April 1997, printed by Formara Ltd., Southend on Sea, Essex, UK.

68. Ponton G., 1997. Experince of DAF plants in West of Scotland Water. Conference proceedings, CIWEM (Chartered Institution of Water Institution and Environmental Management) International Conference on Dissolved Air Flotation in Water Treatment - 
an art or a science?, London, UK, April 1997, printed by Formara Ltd., Southend on Sea, Essex, UK.

69. Tanaka T.S. and Pirbizari M., 1986. Effects of cationic polyelectrolytes on the removal of suspended particulates during direct filtration. $J A W W A, 72$, pp. 57-65.

70. Okada K. and Akagi Y., 1987. Methods and apparatus to measure the $\zeta$ potential of bubbles. Jour. Chem. Eng. Japan, 20, pp.11-15.

71. Bourbigot M-M., Martin N., Faivre M., Le Corre K. and Quennell S., 1991. Efficiency of ozoflotation-filtration process for the treatment of the River Thames at Walton Works. J. Water SRT-Aqua, 40, 2, pp. 88-96.

72. Baron J., Martin Ionesco N. And Bacquet G., 1997. Combining flotation and ozonation the FLOTTAZONE process. Conference proceedings, CIWEM (Chartered Institution of Water Institution and Environmental Management) International Conference on Dissolved Air Flotation in Water Treatment - an art or a science?, London, UK, April 1997, printed by Formara Ltd., Southend on Sea, Essex, UK.

73. Betzer N., Argaman Y. and Kott Y., 1980. Effluent treatment and algae removal by ozone-induced flotation. Water Research, 14, pp. 1003-1009.

74. O'Connell J.K., Phillips N.R. and Lutz C.A., 1997. Pilot testing and implementation of full-scale dissolved air flotation, intermediate ozonation, and high rate filtration for public water supply in the United States of America - case study. Conference proceedings, CIWEM (Chartered Institution of Water Institution and Environmental Management) International Conference on Dissolved Air Flotation in Water Treatment - an art or a science?, London, UK, April 1997, printed by Formara Ltd., Southend on Sea, Essex, UK.

75. Markham L., Porter M. and Schofield T., 1997. Algal and zooplankton removal by dissolved air flotation in Severn Trent Ltd. surface water treatment works. Conference proceedings, CIWEM (Chartered Institution of Water Institution and Environmental Management) International Conference on Dissolved Air Flotation in Water Treatment an art or a science?, London, UK, April 1997, printed by Formara Ltd., Southend on Sea, Essex, UK.

76. Edwards M. and Benjamin M.M., 1991.A mechanistic study of ozone-induced particle destabilisation. JAWWA, 83, pp. 96-105.

77. Hoyer O., Lusse B. and Bernhardt H., 1985. Isolation and characterisation of Extracellular Organic Matter (EOM) from algae. Z. Wasser-Abwasser Forsch., 18, pp. 76-90.

78. Lusse B., Hoyer O. and Soeder C.J., 1985. Mass cultivation of planktonic freshwater algae for the production of Extracellular Organic Matter (EOM)., Z. Wasser-Abwasser Forsch., 18, pp. 67-75.

79. Fogg G.E., Nalewajko, Czeslawa, Watt W.D., 1965. Extracellular products of phytoplankton photosynthesis. Proceedings Royal Society (B), 162, pp. 517-534.

80. Bernhardt H. et al., 1985. Reaction mechanisms involved in the influence of algogenic organic matter on flocculation., Z. Wasser-Abwasser Forsch., 18, pp. 18-30.

81. Fillela M, Buffle J. And Leppard G.G., 1992. Characterisation of submicron colloids in freshwaters : evidence for their bridging by organic structures. Proceedings from the IAWQ/IWSA Joint Specialised Conference on Control of Organic Material by Coagulation and flocculation processes, pp. 71-80.

82. Paralkar A. And Edzwald J.K., 1996. Effect of ozone on EOM and coagulation., JAWWA, 88, pp. 143-154. 
83. Mathonnet S., Casselas C., Bablon G. and Bontoux J., 1985. Impact of preozonation on the granulometric distribution in suspension. Ozone Science \& Engineering, 7, pp. 107 120.

84. Edwards M., Benjamin M.M. and Tobiason J.E., 1994. Effect of ozonation on NOM using polymer alone and polymer/metal salt mixtures. $J A W W A, 86, \mathrm{pp}$. 105-116.

85. Edzwald J.K. and Paralkar A., 1992. Algae, coagulation and ozonation. Chemical water and wastewater treatment II, Klute R. And Hahn H. (Eds.), Springer-Verlag, pp. 24-35.

86. Alaerts G.J. and Van Haute A., 1982. Stability of colloid types and optimal dosing in water flocculation. In : Pawlowski L., ed. Physicochemical Methods for Water and Wastewater Treatment. Amsterdam, the Netherlands : Elsevier, pp.13-29.

87. AWWA Committee Report, 1982. Survey of polyelectrolyte coagulant use in the United States. JAWWA, 74, pp. 600-608. 


\section{REFERENCES}

1. Schippers J.C., 1989. Vervuiling van Hyperfiltratiemembranen en verstopping van infiltratiepunten (Fouling of reverse osmosis membranes and clogging of artificial recharge wells). Ph.D. thesis, Keuringsinstituut voor Waterleidingartikelen - KIWA N.V., Rijswijk, the Netherlands.

2. Kooij van der D., 1992. Assimilable organic carbon as an indicator of bacterial regrowth. J. $A W W A, 84,2$.

3. Vlaški A. and van Breemen N., 1992. A preliminary investigation of the membrane filtration index and characterisation of particles of water produced at WRK III treatment plant. Internal communication, Delft University of Technology, the Netherlands.

4. Vlaški A., van Breemen A.N. and Alaerts G.J., 1996. The algae problem in the Netherlands from a water treatment perspective. J. Water SRT-Aqua, 45, 4, pp. 184-194.

5. Oskam G. and van Genderen J., 1995. Eutrophication and development of algae in surface water - a threat for the future ? Conference paper,. Special subject 8, IWSA Congress, Durban, South Africa.

6. Evans R., 1957. Review of experiences with microstrainer installations. J. AWWA, 49, 5, pp. 541-552.

7. Janssens J.G., van Hoof F. and Dirckx J.J., 1987. Comparative study on preozonation and prechlorination applied in treatment of surface waters from impounding reservoirs. Proc. AWWA Annual Conference, Kansas City, MO., USA.

8. Jodlowski A., 1990. Preoxidation effects on algae related to direct filtration water treatment. Internal communication, Delft University of Technology, the Netherlands.

9. Langlais B., Reckhow D.A. and Brink D.R. (Eds.), 1991. Ozone in Water Treatment, Applications and Engineering. AWWA and Campagnie Generale des Eaux, Lewis Publishers, USA.

10. Jun Ma and Guibai $\mathrm{Li}, 1992$. Laboratory and full scale plant studies of potassium permanganate oxidation as an aid in coagulation. Proc. IAWQ/IWSA Joint Specialised Conference : Control of Organic Material by Coagulation and Floc Separation Processes, Geneva, Switzerland.

11. Petruševski B., van Breemen A. N. and Alaerts G.J., 1993. Pretreatment in relation to direct filtration of impounded surface waters. Proc. European Water Filtration Congress, $K V I V$, Oostende, Belgium.

12. Petruševski, B., 1996. Algae and particle removal in direct filtration of Biesbosch water. Ph.D. thesis TU and IHE - Delft, published by A.A. Balkema, the Netherlands.

13. Raman, R.K., 1985. Controlling algae in water supply impoundments. J. $A W W A, 77$, pp. 41-43.

14. Nederlands Normalisatie Instituut, 1982. NEN: 6460: Water - Determination of iron content by atomic absorption spectrometry (flame technique).

15. Nederlands Normalisatie Instituut, 1982. NEN: 6466: Water - Determination of manganese content by atomic absorption spectrometry (graphite furnace technique).

16. APHA, AWWA and WPCF, 1985. Standard methods for examination of water and wastewater. Am. Publ. Health Assoc., Washington D.C., USA.

17. Bruggink C., Rossum van W.J.M. and Smeenk J.G.M.M., 1995. Method for $\mathrm{BrO}_{3}$. determination in surface drinking water, based on ion chromatography with macroinjection, $\mathrm{H}_{2} \mathrm{O}, 28,11, \mathrm{pp}$.343-347. 
18. Rijk de, S.E., van der Graaf, J.H.J.M. and den Blanken, J.G., 1994. Bubble size in flotation thickening. Wat. Res., 28, 2, pp. 465-473.

19. Vlaski A., van Breemen A.N. and Alaerts G.J, 1996. The role of particle size and density determining dissolved air flotation and sedimentation efficiency. Proc. 4th IAWQ-IWSA International Conference The Role of Particle Characteristics in Separation Processes, Jerusalem, Israel.

20. Vlaški A., van Breemen A.N. and Alaerts G.J., 1995. Optimisation of coagulation conditions for the removal of cyanobacteria by dissolved air flotation or sedimentation. J.Water SRT-Aqua, 45, 5, pp. 253-261.

21. Janssens J.G., 1990. The application of dissolved air flotation in drinking water production, in particular for removing algae. Conference paper, DVGW Wasserfachlichen Aussprachetagung, Essen, Germany.

22. Edzwald J.K., 1994. Principles and application of dissolved air flotation. Keynote address, IAWQ-IWSA-AWWA Joint Specialised Conference on Flotation Processes in Water and Sludge Treatment, Orlando, USA.

23. Bernhardt H. and Clasen J., 1991. Flocculation of micro-organisms - J.Water SRT-Aqua, 40, 2, pp. 76-87.

24. Malley J.P. and Edzwald J.K., 1991. Laboratory comparison of DAF with conventional treatment - J. $A W W A, 83$, pp. 56-61.

25. Arnold R.S. and Harvey P., 1994. Recent applications of DAF pilot studies and full scale design. Proc. IAWQ-IWSA-AWWA Joint Specialised Conference on Flotation Processes in Water and Sludge Treatment, Orlando, USA.

26. Lawler D.L., 1993. Physical aspects of flocculation : from microscale to macroscale -Wat. Sci. Tech., 27, 10, pp. 165-180.

27. Fillela M., Buffle J. and Leppard G.G., 1992. Characterisation of submicron colloids in freshwaters : evidence for their bridging by organic structures. Proc. IAWQ/IWSA Joint Specialised Conference on Control of Organic Material by Coagulation and Flocculation Processes, pp. 71-80.

28. Buffle J. And Leppard G.G., 1995. Characterization of aquatic colloids and macromolecules. 1. Structure and behaviour of colloidal material. Environmental Science \& Technology, 29, 9, pp. 2169-2175.

29. Petruševski B., van Breemen A.N. and Alaerts G.J., 1995. Effect of permanganate pretreatment and coagulation with dual coagulants on algae removal in direct filtration. Proc. IAWQ/IWSA Workshop on Removal of Microorganisms From Water and Wastewater, Amsterdam, the Netherlands.

30. Edzwald J.K. and Paralkar A., 1992. Algae, coagulation, and ozonation - Chemical Water and wastewater treatment II, Klute R. and Hahn H.(Eds.), Springer-Verlag, pp. 263-279.

31. Chang S.D. and Singer P.C., 1988. The impact of ozonation on removal of particles, TOC and THM precursors. Proc. AWWA Anmual Conference, Orlando, Florida, USA.

32. Reckhow D.A., Singer P.C. and Trussel R.R., 1986. Ozone as a coagulant aid. Proc. AWWA National Conference : Recent Actuances and Research Needs, USA.

33. Singer P.C., 1990. Assessing ozonation research needs in water treatment. $J . A W W A, 82$, pp.78-88.

34. Sukenik A., Teltch B., Wachs A.W., Shelef G., Nir I. and Levanon D., 1987. Effect of oxidation on microalgal flocculation. Wat. Res., 21, 5, pp 533-539.

35. Vlaški A., van Breemen A.N. and Alaerts G.J., 1996. The application of ozone for improved algae flocculation and DAF removal. In prep. 
36. Orlandini E., Siebel M.A., Graveland A. and Schippers J.C., 1994. Pesticide removal by combined ozonation and GAC filtration, Water Supply, 14, pp. 99-108.

37. Vlaški A., van Breemen A.N. and Alaerts G.J., 1996. The application of $\mathrm{KMnO}_{4}$ for improved algae flocculation and DAF removal. In prep.

38. Edwards M. and Benjamin M.M., 1992.Effect of preozonation on coagulant-NOM reactions. $J A W W A, 84$, pp. 63-72.

39. Ma J., Graham N. and Li G., 1997. Effect of permanganate preoxidation in enhancing the coagulation of surface waters-laboratory case studies. J.Water SRT-Aqua, 46, 1, pp. 1-10.

40. Edzwald J.K., 1993. Coagulation in drinking water treatment : particles, organics and coagulants. Wat. Sci. Tech., 27 (11).

41. Vlaški A., van Breemen A.N. and Alaerts G.J., 1996. Evaluation and verification of the single collector collision efficiency dissolved air flotation (DAF) kinetic model. In prep.

42. Tobiason J. E., Johnson G.S., Westerhoff P.K. and Vigneswaran B., 1993. Particle and chemical effects on contact filtration performance. Journal of Environmental Engineering, 119, 3, pp. 520-539.

43. Mackie R.I. and Bai R., 1993. The role of particle size distribution in the performance and modelling of filtration. Wat. Sci. Tech., 27, 10, pp. 19-34.

44. Petruševski B., van Breemen A. N. and Alaerts G.J., 1994. Optimisation of coagulation conditions for in-line direct filtration. Proc. Workshop on Optimal Dosing of Coagulants and Flocculants, Mülheim an der Ruhr, Germany. 
size fraction resulted in a relative floc density decrease and a consecutive increase in DAF efficiency. While for sedimentation the floc size - density relation directly affects the efficiency, bubble size and bubble concentration are an additional factor of influence for DAF. Particle and bubble characterisation can further allow calculation of the floc size - density ratio (p) and the absolute floc density $\left(\rho_{\mathfrak{f}}\right)$, important parameters in DAF and sedimentation model equations.

\section{REFERENCES}

1. Bernhardt H. and Clasen J., 1991. Flocculation of micro-organisms. J. Water SRT-Aqua, 40, 2, pp. 76-87.

2. Ives K.J., 1950. The significance of surface electric charge on algae in water purification. J. Biochem. Microbiol. Technol. Engineer. 1, pp. 37-47.

3. Edzwald J.K., 1993. Algae, bubbles, coagulants and dissolved air flotation. Wat. Sci. Tech., 27, 10, 67-81.

4. Petruševski B., Vlaški A., van Breemen A. N. and Alaerts, G.J., 1993. Influence of algal species and cultivation conditions on algal removal in direct filtration. Wat. Sci. Tech., 27, pp. 211-220.

5. Vlaški A., van Breemen A.N. and Alaerts G.J., 1996. The algae problem in the Netherlands from a water treatment perspective. J. Water SRT-Aqua, 45, 4, pp. 184-194.

6. Spicer P.T. and Pratsinis S.E., 1996. Shear-induced flocculation : the evolution of floc structure and the shape of the size distribution at steady state. Wat Res., 30, 5, pp. 10491056.

7. Hanson A.T. and Cleasby J.L., 1990. The effect of temperature on turbulent flocculation: fluid dynamics and chemistry. $J A W W A, 82$, pp. 56-73.

8. Valade M.T., Edzwald J.K., Tobiason J.E., Dahlquist J., Hedberg T. and Amato T. 1996. Particle removal by flotation and filtration : pretreatment effects. $J A W W A, 88, \mathrm{pp}$. 35-47.

9 Edzwald J.K., 1994. Principles and application of dissolved air flotation. Opening address of the Joint LAWQ-IWSA Specialised Conference on Flotation Processes in Water and Sludge Treatment, Orlando, USA.

10. Malley J.P. and Edzwald J.K., 1991. Concepts for dissolved-air flotation treatment of drinking waters - J. Water SRT-Aqua, 40, 1, pp. 7-17

11. Fukushi K., Tambo N. And Matsui Y., 1994. A kinetic model for dissolved-air flotation in water and wastewater treatment. Proc. Joint IAWQ-IWSA Specialised Conference on Flotation Processes in Water and Sludge Treatment, Orlando, USA

12. Janssens J.G., 1990. The application of dissolved air flotation in drinking water production, in particular for removing algae. DVGW Wasserfachlichen Aussprachetagung Essen, Germany.

13. Van Puffelen J., 1993. Flotation - State of the art, Cursus modeme drinkwaterzuiveringstechnieken (Course Modem Water Treatment Technologies), Technical University-Delft, Delft, the Netherlands.

14. Petruševski B., van Breemen A. N. and Alaerts G.J., 1994. Optimisation of coagulation conditions for in-line direct filtration. Proc. Workshop on Optimal Dosing of Coagulants and Flocculants, Mülheim an der Ruhr, Germany.

15. Edzwald J.K. and Wingler B.J., 1990. Chemical and physical aspects of DAF for the removal of algae. J. Water SRT-Aqua, 39, pp. 24-35. 
16. Jun $\mathrm{Ma}$ and Guibai $\mathrm{Li}, 1992$. Laboratory and full scale plant studies of potassium permanganate oxidation as an aid in coagulation. Proc. IAWQ/IWSA Joint Specialised Conference : Control of Organic Material by Coagulation and Floc Separation Processes, Geneva, Switzerland.

17. Reckhow D.A., Singer P.C. and Trussel R.R., 1986. Ozone as a coagulant aid - Proc. AWWA National Conference : Recent Advances and Research Needs, USA.

18. Petruక̌evski B., van Breemen A N. and Alaerts G.J., 1993. Pretreatment in relation to direct filtration of impounded surface waters. Proc. European Water Filtration Congress, KVIV, Oostende, Belgium.

19. Petruševski B., van Breemen A.N. and Alaerts G.J., 1995. Effect of permanganate pretreatment and coagulation with dual coagulants on particle and algae removal in direct filtration. Proc. IAWQ-IWSA Workshop on Removal of Microorganisms from Water and Wastewater, Amsterdam, the Netherlands.

20. Langlais B., Reckhow D.A. and Brink D.R., editors, 1991. Ozone in Water Treatment, Applications and Engineering. AWWA and Campagnie Generale des Eaux, Lewis Publishers.

21. Petruševski, B., 1996. Algae and particle removal in direct filtration of Biesbosch water. Ph.D. thesis TU and IHE - Delft, published by A.A. Balkema, the Netherlands

22. Edwards M., Benjamin M.M. and Tobiason J.E., 1994. Effect of ozonation on NOM using polymer alone and polymer/metal salt mixtures. $J A W W A, 86, \mathrm{pp} .105-116$.

23. Rijk de, S.E., van der Graaf, J.H.J.M. and den Blanken, J.G. (1994). Bubble size in flotation thickening. Wat. Res., 28, 2, pp. 465-473.

24. Bhargava D.S. and Rajagopal K., 1992. An integrated expression for settling velocity of particles in water. Wat. Res., 26, 7, pp. 1005-1008.

25. Patry G.G. and Takacs I., 1992. Settling of flocculent suspensions in secondary clarifiers. Wat. Res. , 26, 4, pp. 473-479.

26. Vlaški A., van Breemen A.N. and Alaerts G.J., 1995. Optimisation of Coagulation Conditions for the Removal of Cyanobacteria by Dissolved Air Flotation or Sedimentation, J.Water SRT-Aqua, 45, 5, pp. 253-261.

27. Alaerts G.J. and Van Haute A., 1981. Stability of colloid types and optimal dosing in water flocculation. Physicochemical Methods for Water and Wastewater Treatment, Pawlowski, L. (eds.), Elsevier Publ., New York/Amsterdam.

28. Bernhardt H. and Clasen J., 1992. Studies on the removal of planktonic algae by flocculation and filtration. Proc. 8th ASPAC-IWSA Regional Water Supply Conference, Kuala Lumpur, Malaysia, October 26-30.

29. Malley J.P., 1994. The use of selective and direct DAF for removal of particulate contaminants in drinking water treatment. Conference paper, IAWQ-IWSA Joint Specialised Conference on Flotation Processes in Water and Sludge Treatment, Orlando, USA.

30. Edzwald J.K. and Paralkar A., 1992. Algae, coagulation and ozonation - chemical water and wastewater treatment $I l$. Klute, R. and Hahn, H. (eds.), Springer-Verlag.

31. Vlaški A., van Breemen A.N. and Alaerts G.J., 1996. Evaluation and verification of the single collector collision efficiency dissolved air flotation (DAF) kinetic model. In prep., IHE-Delft, the Netherlands.

32. Boller M. A. and Kavanaugh M. C., 1995. Particle characteristics and headloss increase in granular media filtration. Wat. Res., 29, 4, pp. 1139-1149. 
33. Box G.E.P., 1954. The exploration and exploitation of response surfaces : some general considerations and examples. Biometrics, 10, pp. 16.

34. Hill W.J. and Hunter W.G., 1966. A review of response surface methodology : A literature survey. Technometrics, 8, pp. 571.

35. Gregory J., 1993. The role of colloid interactions in solid-liquid separation. Wat. Sci. Tech. 27, 10, pp. 1-17.

36. Schers G.J. and van Dijk J.C., 1992. Flotatie, de theorie en de praktijk (Flotation, the theory and the practice). $\mathrm{H}_{2} \mathrm{O}, 25,11, \mathrm{pp} .282-290$. 
negligible or even adverse effects on process efficiency.

The single collector collision efficiency DAF kinetic model can be a valuable tool in the design of DAF plant facilities, as well as for DAF experimental design, since it defines a range of coagulation/flocculation and DAF process parameters that affect the DAF process efficiency. Physical verification of the model, however, largely relies on the accurate prediction of $\alpha_{p b}$. Determination of this lump coefficient largely depends on the coagulation/flocculation process. The role of raw water quality factors affecting the coagulation/flocculation and DAF process efficiency, such as NOM presence, concentration and composition, the presence of surface active agents, etc. must also be considered. The modelling assumption of treating particlebubble collision as the only relevant mechanism for their aggregation, while neglecting other proposed mechanisms such as entrapment of bubbles within a condensing network of flocs and growth of bubbles from nuclei within flocs is not fully justified. However, these mechanisms are complex and difficult to model, in view of their dependance of the water quality.

\section{REFERENCES}

1. Edzwald J.K. and Wingler B.J., 1990. Chemical and physical aspects of dissolved air flotation for the removal of algae - J. Water SRT-Aqua, 39, pp. 24-35.

2. Edzwald J.K., 1993. Algae, bubbles, coagulants, and dissolved air flotation - Water Science and Technology, 27, 10, pp. 67-81.

3. Zabel T., 1992. The advantages of dissolved air flotation for water treatment. $J A W W A$, 77, pp. 42-46.

4. Janssens J.G., 1990. The application of dissolved air flotation in drinking water production, in particular for removal of algae. DVGW Wasserfachlichen Aussprachetagung, Essen, Germany.

5. Gregory R., 1997. Summary of general developments in DAF for water treatment since 1976. Proc. CIWEM (Chartered Institution of Water Institution and Environmental Management) International Conference on Dissolved Air Flotation in Water Treatment - An Art or a Science?, London, UK.

6. Malley J.P. and Edzwald J.K., 1991. Concepts for dissolved-air flotation treatment of drinking waters - J. Water SRT-Aqua, 40, 1, pp. 7-17.

7. Schers G.J. and van Dijk J.C., 1992. Flotatie, de theorie en de praktijk. (Flotation, the theory and the practice) $\mathrm{H}_{2} \mathrm{O}, 25,11, \mathrm{pp} .282-290$

8. Kitchener J.A. and Gochin R.J., 1981. The mechanism of dissolved air flotation for potable water : basic analysis and proposal. Wat. Res., 15, pp. 585-590.

9. Fukushi K., Tambo N. and Matsui Y., 1994. A kinetic model for dissolved air flotation in water and wastewater treatment. Proc. Joint specialised conference on Flotation Processes in Water and Sludge Treatment, Orlando, FL, USA.

10. Edzwald J.K., 1997. Contact zone modelling and the role of pretreatment in dissolved air flotation performance. Proc. CIWEM (Chartered Institution of Water Institution and Environmental Management) International Conference on Dissolved Air Flotation in Water Treatment - an Art or a Science?, London, UK.

11. Han M, Dockko S. and Park C., 1997. Collision efficiency factor of bubble and particle $\left(\alpha_{\mathrm{pb}}\right)$ in DAF. Proc. CIWEM (Chartered Institution of Water Institution and 
Environmental Management) International Conference on Dissolved Air Flotation in Water Treatment - an Art or a Science?, London, UK.

12. Reay D. and Ratcliff G. A., 1973. Removal of fine particles from water by dispersed air flotation : effects of bubble size and particle size on collection efficiency. The Canadian Journal of Chemical Engineering, 51, pp. 178-185.

13. Flint L.R. and Howarth W.J., 1971. The collision efficiency of small particles with air bubbles - Chemical Engineering Science, Pergamon Press, 26, pp.1155-1168.

14. Bernhardt H. and Clasen J. 1991. Flocculation of micro-organisms. J.Water SRT-Aqua, 40, 2, pp. 76-87.

15. Gregory J., 1993. The role of colloid interactions in solid-liquid separation. Wat. Sci. Tech. 27, 10, pp. 1-17.

16. Malley J.P. and Edzwald J.K., 1991. Laboratory comparison of DAF with conventional treatment - J. AWWA, 83, pp. 56-61.

17. Vlaški A., van Breemen A.N. and Alaerts G.J., 1995. Optimisation of coagulation conditions for the removal of cyanobacteria by dissolved air flotation or sedimentation, J. Water SRT-Aqua, 45, 5, pp. 253-261.

18. Petruševski B., 1996. Algae and particle removal in direct filtration of Biesbosch water. Ph.D. thesis TU and IHE - Delft, published by A.A. Balkema, the Netherlands.

19. De Groot C.P.M. and van Breemen A., 1987. Ontspanningsflotatie en de bereiding van drinkwater. Mededeling van de Vakgroep Gezondheidstechniek \& Waterbeheersing, Faculteit der Civiele Techniek, Technische Universiteit Delft, (Dissolved flotation and the preparation of drinking water. Internal Communication Report of the Sanitary Engineering and Water Management Group, of the Civil Engineering Faculty, Technical University Delft, the Netherlands).

20. Oldenziel D.M., 1979. Bubble cavitation in relation to liquid quality. Ph.D. thesis, Enschede, the Netherlands.

21. Haarhoff J. And Steinbach S., 1997. Towards maximal utilisation of air in dissolved air flotation. Proc. CIWEM (Chartered Institution of Water Institution and Environmental Management) International Conference on Dissolved Air Flotation in Water Treatment - an Art or a Science?, London, UK.

22. Steinbach S. And Haarhoff J., 1997. Air precipitation efficiency and its effects on the measurements of saturator efficiency. Proc. CIWEM (Chartered Institution of Water Institution and Environmental Management) International Conference on Dissolved Air Flotation in Water Treatment - an Art or a Science?, London, UK.

23. Tambo N., Igarashi T. and Kiyotsuka M., 1985. An electrophoretic study of air bubble attachment to aluminium clay/colour flocs. J.JWWA, 604, pp. 2-6.

24. Okada K. and Akagi Y., 1987. Methods and apparatus to measure the $\zeta$-potential of bubbles. Jour. Chem. Eng. Japan, 20, pp. 11-15.

25. Ives K.J., 1995. The inside story of water treatment processes. J.Environmental Engineer. pp. 846-849.

26. Edzwald J.K., 1994. Principles and applications of dissolved air flotation - Keynote address, Joint specialised conference on Flotation Processes in Water and Sludge Treatment, Orlando, FL, USA.

27. Yao K.M., Habibian M.T. and O'Melia C.R., 1971. Water and waste water filtration: concepts and applications. Environmental Science \& Technology, 5, 11, pp.1105-1112.

28. Ives K.J., 1960. The significance of surface electric charge on algae in water 
purification. J. Biochem. Microbiol. Technol. Engineer. 1, pp. 37-47.

29. Malley J.P., 1994. The use of selective and direct DAF for removal of particulate contaminants in drinking water treatment. Conference paper, Joint specialised conference on Flotation Processes in Water and Sludge Treatment, Orlando, FL, USA.

30. Nakamura T., Adachi Y. and Suzuki, M., 1993. Flotation and sedimentation of a single Microcystis floc collected from surface bloom. Wat. Res. , 27, 6, 979-983.

31. Nakagawa M., Takamura Y. and Yagi O., 1987. Isolation and characterization of the slime from a cyanobacterium Microcystis aeruginosa K-3A. Agric. Biol. Chem. 51, pp. 329-338.

32. Petruševski B., Vlaski A., van Breemen A. N. and Alaerts, G.J., 1993. Influence of algal species and cultivation conditions on algal removal in direct filtration. Wat. Sci. Tech., 27, pp. 211-220.

33. Roberts K.L., Weeter D.W. and Ball R.O., 1978. Dissolved air flotation performance. Proc., 33rd Industrial Waste Conference, Purdue University, USA.

34. Fawcett N.S.J., 1997. The hydraulics of flotation tanks : computational modelling. Proc. CIWEM (Chartered Institution of Water Institution and Environmental Management) International Conference on Dissolved Air Flotation in Water Treatment an Art or a Science?, London, UK.

35. Shawcross J., Tran T., Nickols D. And Ashe C.R., 1997. Pushing the envelope : dissolved air flotation at ultra-high rate. Proc. CIWEM (Chartered Institution of Water Institution and Environmental Management) International Conference on Dissolved Air Flotation in Water Treatment - an Art or a Science?, London, UK.

36. Breese S., 1997. Use of comutational fluid dynamics in the design and optimisation of DAF basins. Proc. CIWEM (Chartered Institution of Water Institution and Environmental Management) International Conference on Dissolved Air Flotation in Water Treatment - an Art or a Science?, London, UK.

37. O'Neill S. And Oddie G., 1997. Physical modelling study of the dissolved air flotation process. Proc. CIWEM (Chartered Institution of Water Institution and Environmental Management) International Conference on Dissolved Air Flotation in Water Treatment an Art or a Sience?, London, UK.

38. Ta C.T. and Brignal W.J., 1997. Application of single phase computational fluid dynamics techniques to dissolved air flotation tank studies. Proc. CIWEM (Chartered Institution of Water Institution and Environmental Management) International Conference on Dissolved Air Flotation in Water Treatment - an Art or a Science?, London, UK.

39. Dahlquist J., 1997. The state of DAF development and applications to water treatment in Scandinavia. Proc. CIWEM (Chartered Institution of Water Institution and Environmental Management) International Conference on Dissolved Air Flotation in Water Treatment - an Art or a Science?, London, UK.

40. APHA, AWWA and WPCF, 1985. Standard methods for examination of water and wastewater, Am. Publ. Health Assoc., Washington D.C., USA.

41. Nederlands Normalisatie Instituut, 1982. NEN: 6460: Water - Determination of iron content by atomic absorption spectrometry (flame technique).

42. Nederlands Normalisatie Instituut, 1982. NEN: 6466: Water - Determination of manganese content by atomic absorption spectrometry (graphite furnace technique). 
43. Rijk de S.E. and Graaf van der J.H.J.M. and Blanken den J.G., 1994. Bubble size in flotation thickening - Water Research, 28, 2, 465-473.

44. Boller M. A. and Kavanaugh M. C., 1995. Particle characteristics and headloss increase in granular media filtration. Wat. Res., 29, 4, pp. 1139-1149.

45. Alaerts G.J. and Van Haute A., 1981. Stability of colloid types and optimal dosing in water flocculation. Physicochemical Methods for Water and Wastewater Treatment, Pawlowski, L. (eds.), Elsevier Publ., New York/Amsterdam.

46. Filella M., Buffle J. and Leppard G.G., 1993. Characterisation of submicron colloids in freshwater : Evidence for their bridging by organic structures. Wat. Sci. Tech., 27, 11, pp. 91-102.

47. Buffle J. and Leppard G.G., 1995. Characterization of aquatic colloids and macromolecules. Structure and behaviour of colloidal material. Environmental Science and Technology, 29, 9, pp. 2169-2175.

48. Takahashi T., Miyahara T. and Mochizuki H., 1979. Fundamental study of bubble formation in dissolved air pressure flotation. Journal of Chemical Engineering of Japan, 12, 4, 275-280. 